\title{
New Forms of Mobilization, New People Mobilized? \\ Evidence from the Comparative Study of Electoral Systems
}

\section{Accepted version at Party Politics.}

\author{
Pedro C. Magalhães \\ Institute of Social Sciences-ULisbon, Portugal
}

John H. Aldrich

Duke University, USA

Rachel K. Gibson

University of Manchester, UK

\begin{abstract}
Mobilization efforts by parties and candidates during election campaigns tend to reach those who are more likely to vote in the first place. This is thought to be particularly consequential for turnout among the young. Harder and less cost-effective to reach, young adults are less mobilized and vote less often, creating a vicious circle of demobilization. However, new forms of political communication - including online and text messaging have created expectations this circle might be broken. Is this happening? We examine data from Module 4 of the CSES surveys, looking at the prevalence of different types of party contacts in 38 countries, the profile of voters who are reached, and the effects of these efforts on turnout. New forms of party contacting do matter for turnout and partially reduce the age gap in contacting, but still fail to compensate for the much larger differentials that persist in traditional forms of contacting.
\end{abstract}

Keywords: mobilization; party contacts; turnout 


\section{Introduction}

Since Rosentstone and Hansen's pathbreaking account (1993), many have studied the effect of mobilization efforts on political engagement. Some, although fewer, have examined conditions under which such contacts affect turnout decisions. Even fewer have looked at different types of contact across countries, even though the technologies available for partisan mobilization have expanded dramatically in recent years. Here, we seek to address this gap using a new and important source of survey data - Module 4 of the Comparative Study of Electoral Systems - that measures different modes of campaign contacting across 38 countries. $^{1}$

Explanations of turnout are diverse, including such key explanatory variables as resources (Verba, Schlozman, and Brady 1995), psychological involvement (Milbrath and Goel 1977), interpersonal networks (Huckfeldt and Sprague 1995), social attachments (Putnam 2001) - especially partisan attachments (Shaffer 1981) - and institutional factors interacting with all or some of the previous (Anduiza Perea 2002). Rosenstone and Hansen (1993) focused on mobilization as a determinant of turnout, especially the efforts of political parties and candidates to stimulate voting. We know that such contacts are skewed toward more active and involved voters and are thus likely to increase existing differences in participation (Gershentson 2003) notably exacerbating differences in participation between younger and older citizens (Karp et al. 2008; Stevens and Bishin 2011). The almost universal lower turnout rates among the young (Milbrath 1965; Blais 2000) has been explained by fewer resources (Glenn and Grimes 1968), weaker social attachments (due to geographical mobility, lower rates of marriage and weaker community and economic ties), and weaker political attachments, especially to party and ideology in particular (Strate et al. 1989; Achen and Sinnott 2007). But the fact that parties are also less able or willing to mobilize the young seems add to a vicious cycle that "disconnects the political world from young citizens" (Nickerson 2006: 48).

In this article, we ask whether the development of new forms of party contacting has reduced this age gap. CSES's Module 4 includes measures of self-reported mobilization contacts by parties and candidates not only through such traditional means as face-to-face, mail, and leaflet contacting, but also through the use of newer mobilization tools, such as

\footnotetext{
${ }^{1}$ The CSES is a post-election survey that is fielded across a range of national elections over a given time period and includes a series of standard questions about political attitudes and behaviour.
} 
texting, e-mailing, and social network messaging and posting. Online social media have often been described as a potential "leveler in terms of motivating political participation" (Holt et al. 2013: 19; see also Gil de Zuniga et al. 2014; and Shirky 2011), including a wide variety of types of political engagement (but see Boulianne 2015 for a more skeptical view). Party campaigns use of these mobilization tools have often been discussed, in particular, in light of their assumed greater potential to reach younger voters (Bosancianu 2014). In at least some countries, they do seem to mobilize them more effectively (Aldrich et al. 2016). But how widespread are these positive effects? Do these new mobilization tools make young adults easier to reach across a wide variety of societies and political systems? What is their contribution to mitigate or even compensate for well-known age gaps in terms of mobilization, engagement, and turnout?

\section{Voter Mobilization: The Story So Far}

Election campaigns have become more professionalized and technologically sophisticated in their mobilization efforts as numerous international studies have attested to (Norris, 2000; Plasser and Plasser, 2002; Farrell and Schmitt-Beck, 2003). These changes have prompted increasing attention to what works and what does not in terms of turning out the vote. While most studies have focused on the case of U.S., the methods used have varied with some scholars using survey data and self-reported contact (Merriam and Gosnell 1924; Cutright 1963; Kramer 1971; Rosenstone and Hansen 1993; Panagopoulos and Francia 2009). Others have conducted field experiments, reviving the pioneering approach of Gosnell in the 1920s. (1927). Such work has taken off particularly since the late 1990s (see Green and Gerber 2016). These different studies have converged, at least, in one key finding: contacts involving live interaction with voters, especially through face-to-face canvassing, do matter for turnout, particularly when messages appeal to social norms (see Green, McGrath and Aronow 2013, Green and York 2017, and Nickerson and Arceneaux 2009 for reviews).

Cross-national surveys, such as those analyzed by Karp and Banducci (2007) and Magalhães (2016) suggest that being contacted prior to an election increases voting in many political systems. Field experiments by John and Brannan (2008) and Fieldhouse et al (2013) reinforced the importance of face-to-face contacting by extending the experimental settings to the UK, and recent work has confirmed these findings elsewhere (Nyman 2017). 
However, this line of research has also suggested that party canvassing is not universally effective (Bhati et al. 2016), while more impersonal methods such as phone and direct mail may be more effective elsewhere than in the U.S. (Cutts et al. 2009).

The growth in use of modes of digital contacting, especially after the extensive use made of online tools in the Obama presidential campaign in 2008 , has reopened these questions. The evidence, so far, has been mixed. Hooghe et al. (2010) reported null findings, Vaccari (2017) got positive findings, while still others (e.g., Aldrich et al., 2016) found heterogeneous results. In terms of specific modes, email messages are seen as one of the least effective prompts (Stollwerk, 2006; Nickerson, 2007; Krueger 2010; Malhotra et al., 2012), while text message reminders to vote appear to have only a somewhat stronger effect (Dale and Strauss, 2009; Malhotra et al., 2011). Findings about messages from social networks also range from small (Bond et al. 2012) to null effects (Brockman and Green 2013; Aldrich et al. 2016).

A few studies examined contacting as a dependent variable. First, not all countries are equal in this respect. Some countries report very high levels of contacting (over $50 \%$ ), while others drop to nearly zero (Karp and Banducci, 2007). Authors point to a range of explanations. Newer democracies, with less well-organized, experienced and resource-rich campaigns, report fewer contacts (Birch 2005). Karp et al. (2008) also show that systems with single member districts (SMD) lead to higher rates of contact, as candidates are more likely to seek out a direct relationship with a voter than in more anonymous list systems. Furthermore, with lower turnout in plurality systems (Powell, 1986), mobilization has more potential to be effective. Systems where parties are more densely concentrated around the ideological center appear to lead to higher mobilization efforts than polarized systems (Karp, 2012).

Karp et al (2008) also identify features of voters that make parties more or less likely to mobilize them. One main finding of this comparative work confirms what we already knew about the US: citizens who are already active and engaged are most likely to be the targeted. Not surprisingly, campaigns try to maximize the impact of their limited resources by directing their efforts toward those who are most likely to respond positively, i.e. those who have previously engaged with politics and who are easier to locate. The significance of other characteristics such as race, socio-economic status, and organized group membership further underscore the idea that campaigns are prioritizing voters who are already engaged. 
Recent work by Panagopolous (2016) has taken this 'preaching to the converted' argument a step further by arguing that advances in micro-targeting mean that parties are now increasingly emphasizing base mobilization compared to riskier strategies that focus on persuading harder to persuade independent or undecided voters.

There is also an age gap in contacting. In the United States, younger people are especially mobile and thus more difficult to reach. Parties seem to have internalized that in their judgment about the cost-effectiveness of resource allocation for mobilization (Nickerson 2006), and the age differential in the probability of being contacted seems to have increased through time (Gershentson 2003). Moving to new forms of campaign mobilization, things are less clear. Krueger (2006) finds in that, in the US, younger people are less likely to be contacted over the Internet. But it is not obvious that these findings will hold either cross-nationally or over time. In the low salience European Parliament elections, for example, Bosancianu (2014) finds that younger people are more likely than older voters to be contacted via the internet.

\section{Data and Results}

CSES data allows us, for the first time, to study different modes of contacting across many democracies. In Module 4's fourth release, data from 38 countries were gathered through national election studies conducted from 2011 through $2016 .{ }^{2}$ That module includes a battery measuring different campaign contacts, several types of which can be broadly divided into "traditional" and "new". The former specifies if the contact was by mail, phone, or in-person. The latter includes e-mails, text messages, and social networks/micro-blogs such as found on Facebook or Twitter.

\section{Cross national variation in levels of contacting}

We first present data comparing levels of the new and traditional forms of mobilization. Figure 1 shows the percentages of respondents in each country that report receiving contacts by parties or candidates during the electoral campaign in these different

\footnotetext{
${ }^{2}$ The Comparative Study of Electoral Systems (www.cses.org). CSES MODULE 4 FOURTH ADVANCE RELEASE [dataset]. April 11, 2017 version. doi:10.7804/cses.module4.2017-04-11.
} 
ways. ${ }^{3}$ The use of mailing and leaflets remains, overall, the most common mode of contacting, followed by face-to-face and phone. Cross-national variations are dramatic, from countries like the UK or New Zealand (where close to $80 \%$ of voters are contacted by direct mail or leaflets) and Ireland or Mexico (where close to half of the electorate reports a faceto-face contact) to countries such as Portugal or Bulgaria (where very few voters report a contact of any kind).

\section{Figure 1 about here}

Figure 2 shows a more direct comparison between being (1) contacted in any way, (2) through any "traditional" mode (face-to-face, mail or phone), or (3) through any "new" mode of contacting (texting, e-mail or social networks). ${ }^{4}$ There is, first, very large variation in the rates of overall contacting. The UK has the highest level of citizens reporting being contacted in some way (close to $90 \%$ in the 2015 election). More than two-thirds of respondents in five other countries - New Zealand, (in both elections), Canada, Switzerland, Mexico (in 2015), and Australia - reported a partisan contact. At the other end are countries such as Romania, Slovenia, Poland, Portugal or Bulgaria where fewer than $10 \%$ of voters reported any type of contact.

\section{Figure 2 about here}

Second, many more voters report being reached through traditional modes than through the newer modes of contacting (as already suggested in Aldrich et al. 2016 and Bosancianu 2014). In no country was as much as a third of the electorate reached by texting, e-mail, or social networks. Finally, Figure 2 already suggests that the new forms of party mobilization mostly seem to reach people who are also contacted in traditional ways. This is more clearly visible in Figure 3. The overwhelming majority of contacted respondents report

\footnotetext{
${ }^{3}$ In some countries/territories, no information about one or more sub-types of contacts: Hong Kong (no data for mail contacts), Canada (phone, texting or e-mail), Ireland (phone or social networks), the UK (texting), Germany (texting), and New Zealand 2011 (texting).

${ }^{4}$ For each type, we leave out the countries where one or more questions about specific types of contacting were not asked.
} 
either traditional modes alone or both traditional and new forms of contact. With the partial exception of Taiwan, South Korea and South Africa, very few individuals are reached exclusively through new forms of mobilization.

\section{Figure 3 about here}

\section{Correlates of Party Contacting}

What drives party mobilization? One part of the answer pertains to the social and electoral context in which individuals are embedded. Greater levels of party contacting have been found in electoral systems with SMD and in older, more established democracies.

Other studies point to the use of winner-take-all electoral rules and party system polarization. We know of no studies that have investigated whether these patterns carry over into the newer forms of mobilization. On the one hand, the relationship between single member districts and mobilization hinges partially on the ability to connect voters to a particular territorial location. While that connection is clear with the traditional modes, it is much more difficult for parties to be confident of territorial location with mobile phone or online contacting. On the other hand, the ability of parties to use these newer modes is likely contingent on the technological readiness of a nation. For example, while in highly economically developed countries such as Finland, the UK or Norway, over $90 \%$, of the population has access to the internet, countries such as Kenya, Thailand and Mexico have $50 \%$ penetration or less. Thus, we should expect, ceteris paribus, that these new forms of party contacting should be more prevalent in the more developed nations.

In Table 1, we take a look at aggregate-level correlations between the prevalence of different types of contact and a series of country-level features, such as the use of winner take all/plurality rules, ${ }^{5}$ the use of SMD, ${ }^{6}$ the age of the democracy, ${ }^{7}$ party system

\footnotetext{
${ }^{5}$ It's a dummy variable coded 1 for countries/elections where a winner-take-all / first past the post rule is employed. This includes presidential elections. See online appendix for sources of this and all other variables. ${ }^{6}$ It's a dummy variable coded 1 for countries/elections employing single member districts, either as the single way of organizing the conversion of votes into seats (example: UK) or as part of a mixed system (example: Germany).

${ }^{7}$ The number of consecutive years, up to the date of the election, each country has been rated " 6 " or above in the variable "polity" of the Polity IV dataset. For Iceland, we consider 1944 as the first year. Hong Kong was coded as 0 .
} 
polarization, ${ }^{8}$ and economic development, ${ }^{9}$ as well as the internet penetration rate and mobile phone subscriptions. The first set of variables has been linked to the prevalence of party contacting in existing broad cross-national studies (Karp and Banducci 2007; Karp 2012), while GDP, internet penetration and mobile phone subscription rates aim at capturing the extent to which the technological capabilities necessary for particular types of contacting are widespread.

\section{Table 1 about here}

Table 1 shows, first, that some of the correlates of contacting proposed in the literature are largely supported in this broad array of democracies. The use of single member districts and age of democracy (the latter employed as a proxy for the level of professionalization of parties in previous studies - Karp and Banducci 2007) appear to be particularly relevant in this regard. Results also reveal that, within the traditional modes of contact, mail and leaflet contacting is most related to these macro factors. In contrast, the prevalence of new modes of contacting seems appears to be weakly related to most of those factors. The only partial exception is GDP per capita, particularly for e-mail contacts.

Turning to the individual level, the primary question here is whether the parties are targeting a different type of potential voter when they use the newer methods.

Traditionally, parties tend to target - and to reach - individuals with more resources, and who have stronger social, partisan and/or ideological ties. A full examination of the role of all relevant individual level characteristics using the CSES dataset is not possible because not all election studies included all relevant measures. ${ }^{10}$ Given data availability and findings about the importance of the variables, we focus on five core micro-level factors - education, partisanship, marital status, gender, and age. ${ }^{11}$ As noted above, we pay special attention to

\footnotetext{
${ }^{8}$ Party system polarization index, which uses the public's mean perception of a party's Left-Right position in each nation, weighted by the vote share for each party.

${ }^{9}$ GDP per capita, at constant 2011 international dollars.

${ }^{10}$ The main missing variables were union membership, church attendance and income. CSES does not include a measure of political interest. It also allows individual election studies latitude in measuring demographic variables.

${ }^{11}$ Education uses a scale of 0 to 9, from "None" to 9 (ISCED level 8, doctoral or equivalent). Partisanship is coded 1 for respondents who answer "Yes" to the question "Do you usually think of yourself as close to any particular party?" Although the CSES survey contains follow-up questions about "degree of closeness" to that
} 
age. First, does the probability of being contacted by a party or candidate follow the wellestablished curvilinear pattern exhibited by the probability of voting itself? Second, to what extent does this hold for the new modes of contacting?

Table 2 shows the results of logistic regression analyses, where the dependent variable is simply whether a voter reports being contacted each particular way. ${ }^{12}$ We show the results of analyses for the six different binary dependent variables. ${ }^{13}$ Based on the exploratory results in Table 1, the macro-level variables employed include age of democracy, SMD, and GDP per capita for each country/year. In the results presented for texting and internet-related contacts, GDP per capita is replaced, respectively, by the number of mobile cellular subscriptions per 100 inhabitants and by the internet penetration rate. ${ }^{14}$ Coefficients are standardized by dividing them by two times the sample's standard deviations.

\section{Table 2 about here}

The results confirm and provide further detail on the key findings from prior analysis of older CSES data (Karp et al 2008; Karp and Banducci 2007). Specifically they show that individuals living in countries with electoral systems employing SMD's are significantly more likely to be mobilized by parties through mail and phone. Similarly, the age of democracy and GDP per capita variables are significantly related to mail contact. The relationships between the individual-level variables and traditional means of contacting support expectations from the literature. Respondents who are more educated, married, and who "feel close to a party" are more likely to report being contacted. The age variable behaves very much as expected: the signs for age and age squared are both significant and suggest a

\footnotetext{
party, it was not asked in all surveys. Marital status is coded 1 for all respondents who are married or living together with a partner. Female is coded 1 for female respondents. Age is years of age.

${ }^{12}$ We estimated multilevel random intercept logistic regression analyses, correcting both for clustering and estimating "average effect" coefficients. We also conducted multicollinearity diagnostics for all regression analyses in this piece. Highest VIF - with obvious exception of the interacted age variable - was 2.15 (for Internet penetration rate, Table 2 , model for e-mail contacts).

${ }^{13}$ For each analysis, we use all countries where the dependent variable is available in the survey, as well as the basic core of individual-level determinants described above and common to all surveys, to minimize loss of cases.

${ }^{14}$ Analyses using GDP per capita were also performed and are reported in the text.
} 
curvilinear relationship between one's age and the probability of being contacted. ${ }^{15}$ We'll $^{\prime}$ examine this aspect in greater detail later. The signs, coefficient sizes and significance for all remaining individual-level variables are relatively similar, with the partial exception of faceto-face contacts, where women are less likely to report being contacted in person than are men, while marital status and education seem to matter less than for other types of traditional contacts.

In columns 3 to 5 , we report the results for the new forms of contacting. E-mail and social network contacting are more prevalent in nations with greater rates of internet penetration. ${ }^{16}$ However, neither the use of SMD's nor age of democracy make a difference in these types of contacts. The greater sensitivity of traditional contacting to institutional context and democratic longevity is intriguing and suggests that those modes are more strategically aligned with the incentives provided in the wider electoral environment. The newer forms, by contrast, appear to be more untethered and less structured by these broader systemic forces, and remain elusive, in terms of macro-correlates, in this analysis. We will return to this point in the final section. Partisans are more likely to be reached in these new ways than non-partisans, similarly to what happens with traditional modes. Finally, education plays an even stronger role for contacting using these new ways.

\section{A deeper dive into age and contacting.}

Figure 4 shows plots of the predicted probability of being contacted by parties or candidates at different ages based on the various models estimated in Table 2, i.e, after controls are introduced. For these plots, we reestimated the models using only the 32 countries for which we have information about all of the types of contacts.

\section{Figure 4 about here}

\footnotetext{
${ }^{15}$ Models were also run with age-cubed, on the possibility that contacting, especially the new forms might affect the youngest cohort(s) differently, with an inflection point before the monotonic increase through the middle cohorts with a second inflection point before the oldest cohort(s) with an expected decline in contacting. In no case, however, was age-cubed significant, and so those are not included here.

${ }^{16}$ In fact, if we replace this variable with GDP per capita (not shown in the table), the coefficient is also positive and significant at traditional levels for these two types of contacts. This is not surprising, given that GDP per capita and internet penetration rates are correlated, at the aggregate level, above .85 .
} 
In almost all modes of contact the relationship between age and being contacted is non-linear, as usual. The exception is being contacted through an online social network. Here we find a nearly linear, negative relationship, with young adults being more likely to report contacts compared with their middle-aged counterparts and even more so than the oldest respondents. However, on average, the probability of being reached in this way across our countries is modest. In all remaining modes, younger voters are less likely to be contacted than most other adults. This is especially so for contacts by mail or phone, and young adults are only marginally more likely to receive a text or e-mail than even the very oldest voters.

Each individual can be exposed to multiple forms of contact. Table 3 reports analyses where we look at, respectively, the correlates of reporting any type of contact, a traditional contact, and one or more kinds of "new" contact. Again, we focus exclusively on the 32 countries on which we have responses for all kinds of contact.

\section{Table 3 about here}

The correlates of being contacted at all and of being contacted through traditional modes (columns 1 and 2) are almost identical, for the simple reason that almost everybody who is contacted in any way is contacted through a traditional mode. Again, use of SMD, level of education, and our indicators of social and partisan attachment emerge as relevant. With respect to those who report new forms of contacting, no coefficient for any macrolevel correlate is significant. There are three other major differences in comparison to traditional contacting. First, females are less likely to be reached. Second, marriage seems to make no difference. And finally, the relationship between the respondent's level of education the probability of being contacted is about twice as strong in comparison with what happens in traditional modes.

Figure 5 shows findings with respect to age. While young adults are apparently less effectively reached by parties by traditional means than the other voters, such disadvantage mostly disappears when new forms of contacting are considered. Here, the oldest voters are least likely to be contacted. However, the lower prevalence of the new types of contacts overall, combined with the fact that young adults are not more likely to be reached in these ways than the middle-aged, produces a perhaps surprising overall result: in the end, when 
considering all kinds of mobilization ("any contact"), young adults remain less targeted than any other type of voter. In other words, the new forms of party contacting have, so far, failed to compensate for the age gap in mobilization.

\section{Figure 5 about here}

Of course, this is the most general picture. What happens on country-by-country basis? We estimated the individual level component of the multilevel logistic models used for Table 3 separately for each of the 20 countries in which we had complete data about traditional and new contacts, and where rates of prevalence of either was above a minimum threshold of 5 percent of the sample (in 12 countries, that prevalence was even lower). Then, we estimated the predicted probabilities of being contacted according to age for each country. Figures $A 1$ to $A 4$ in the online appendix show the results for four groups of countries. The first, the largest (12 countries/elections), replicates the general pattern: overall, younger people report fewer contacts than middle-aged adults (and in some cases, than all other adults), because they are less likely to be contacted in traditional ways, and new forms of contact fail to compensate for that differential. Then, in Sweden and Norway, exceptionally, younger voters are more likely to be contacted by parties in general, but this results from being more contacted both in traditional and in new ways. In a third group of countries/elections (Austria, Czech Republic, Mexico 2015 and Turkey), age and party contacting seem weakly related. Finally, in two cases, while younger adults were less likely to be contacted in traditional ways, they were more likely to be contacted in new ways. And as a result, the probability of being targeted by parties in any way ends up unrelated to age in Mexico in 2012 or with a differential in favor of younger voters in Finland. However, these are the only two cases where new forms of contacting make up the age gap due to traditional forms of contacting. ${ }^{17}$

\footnotetext{
${ }^{17}$ One possibility would be that these different patterns of age/contact relationships would be sensitive to the very distribution of the sampled population each country in terms of age. However, it is interesting to note that, in the country by country analyses presented in the online appendix, those countries with the most deviant age distribution of those surveyed in the CSES (Mexico, South Africa, and Turkey, all characterized by more expansive - broader at the base - pyramids of voting-age population) end up showing different patterns of age/contact relationships. In fact, this even occurs with two different elections in the same country (Mexico).
} 
In sum, with few exceptions, new forms of contact reach small segments of the electorate. They reach a similar profile of voters as traditional contacts, but one even more restricted to men and to the highly educated. Finally, although there is a tendency for younger adults to be less disadvantaged by these new forms of contact, this is not sufficient to overcome the broad age differential in traditional party contacting.

\section{Party contacting and turnout}

What difference does this make? Does being contacted increase the probability of voting? And if so, which mode(s) are effective? We have just seen how party contacts are not randomly assigned. Although this may be partially addressed by controlling for known covariates of turnout, both contacting and turnout can still be systematically related with attributes we were unable to measure (see Gerber et al. 2004). The consequence is that the use of observational data such as those collected in these surveys, compounded by the lack of relevant variables in several countries, increases the risk that any estimates of the relationship between contact and turnout will be biased, much more so than if experimental data were available.

However, well-designed sample-surveys such as those in the CSES permit inferences to population values, something that experiments do not support, and it is nevertheless possible to employ strategies that may reduce - albeit never eliminate - the risk of bias. In Table 4, we show the results of three models of turnout, each employing a different independent variable: if the respondent reported being contacted by a party or candidate in any way; if the respondent reported being contacted just through a traditional mode; or if the respondent reported by contacted both in a traditional and a new way. First, we report the results from a multilevel random intercept logistic regression model, using a single macro-level ordinal variable (Compulsory voting), ${ }^{18}$ as well as from fixed-effects probit, where the cluster variables (countries/elections) enter the model as dummy variables, thus capturing all variability associated with the cluster level. However, we also estimate a fixed effects, recursive, bivariate probit model. Given that we know that people were not contacted by campaigns randomly, and were instead selected (and self-selected) in ways

\footnotetext{
${ }^{18}$ Compulsory voting is pre-coded in the CSES dataset, and recoded here with value 0 from counties without it, 1 for countries where voting is compulsory but without sanctions for violation, 2 with weakly enforced sanctions and 3 for strictly enforced sanctions.
} 
that make being contacted at least partially endogenous, the recursive, bivariate probit procedure is designed to reflect that possibility, by estimating two equations simultaneously; one for the endogenous contact variable and the other for turnout. ${ }^{19}$ Table 4 shows the results.

\section{Table 4 about here}

Consider first the relationship with turnout of the remaining explanatory variables besides contacting. In the multilevel model, the compulsory voting measure is statistically significant and substantively large. Party closeness and education are powerful predictors of turnout in all models. However, their importance is rivaled by that of being contacted by a party in the third set of models, where "contact" is cumulative, i.e., having reported being contacted both in a traditional and in a new way. In sum, institutions and the basic "triad" of individual level variables that explain turnout - resources, attachments, and mobilization efforts - are once again found to be consequential.

Figure 6 shows the marginal effects of the different contact variables on the probability of voting. Interpretation is straightforward. In both our multilevel logit and fixed effects probit models, the probability of turning out is estimated to be about 4 percentage points higher for those who were contacted in any way in comparison with those who were not contacted at all. But strikingly, those who reported being contacted both in traditional and in newer ways were much more likely ( 8 percentage points) to have voted than those not contacted at all.

The bivariate probit estimations have much larger confidence intervals, as usual, and the coefficients for contacting are not significant for either the "any contact" or "traditional contact" variables. However, the estimated effects of the cumulative traditional + new

\footnotetext{
${ }^{19}$ The literature addresses the critical problem of identification of the model parameters. While Maddala (1983) proposed standard exclusion restrictions on the first equation, Wilde (2000) showed that in models with endogenous dummy regressors, exclusion restrictions are not needed, given sufficient variation in the data. In any case, we proceed as follows: in a first stage, we ran separate fixed-effects probit models for both contact and turnout. Ina second stage, we omitted the variables from the equation(s) in which they were insignificant ("married" in all contact equations, "female" in all turnout equations, "female" in the equation for both types of contact), thus satisfying Maddala's stronger restriction empirically.
} 
contact variable are significant and even larger than in the other models. ${ }^{20}$ Furthermore, the diagnostic statistics mitigate our concerns about the need to address selection bias. ${ }^{21}$

\section{Figure 6 about here}

Parties contacting citizens to stimulate mobilization appears to be positively and significantly related to turnout. The four percentage point estimated effect of being contacted by a party in traditional ways is similar to that obtained in other comparative studies (Karp and Banducci 2007; Magalhães et al. 2016). More importantly, the results indicate that new forms of contact may be consequential. Even though they have not greatly expanded the portion of the electorate that was already reached by traditional means, they seem to contribute to a cumulative effect, nearly doubling the propensity to vote beyond what being contacted just through traditional modes are able to achieve, a result that is robust to the estimation strategy employed.

\section{Discussion}

Partisan mobilization efforts are known to focus on particular profiles of voters those who are already engaged and likely to respond. The arrival of digital communication channels has introduced a new and cost-effective way for parties to reach groups less usually contacted - including younger voters - and thus hold the potential to break a vicious cycle of under-mobilization and disengagement. Our analysis, using self-reported contact data from 38 countries, has both positive and negative news in this regard.

Whatever the potential for greater youth mobilization through new methods may be, it has yet to materialize to any substantial degree. While younger people are comparatively more likely to be contacted by parties using these newer methods, the overall frequency of such

\footnotetext{
${ }^{20}$ We ran similar models for those being contacted only via the new forms of contacting. With many fewer receiving such contacts, standard errors are much larger than in the comparable models reported in Table 4 and Figure 6 . In the logit and fixed-effects probit models, contacting is nonetheless statistically significant with a positive but somewhat smaller coefficient. The fixed effects bivariate probit model, however, has a (barely) significant but negative coefficient with a very large standard error. The dramatically larger standard error suggests overfitting with virtual non-convergence, something that does not seem to apply to the measures as reported in Table 4 and Figure 6. Details available on request.

${ }^{21}$ In Table 3, the rho statistics, which show the correlation of the disturbances between the two equations, are negative, small, and not significantly different from zero. Thus, while the negative sign suggests that the effect of contact may be underestimated in simple probit models, the fact that it is not statistically significant implies that the estimates of the single-equation models are essentially unbiased and consistent.
} 
self-reported contact is very limited compared with other more traditional modes. The profile of those contacted is otherwise not particularly different from those contacted in more traditional ways. Indeed, as in the case for education, the socio-political selectivity driving the traditional types of contacting appears to be carried over and reinforced by new forms.

These results are even more intriguing given our subsequent findings that the new forms of contact appear to be successful for mobilization. The interpretation of this, however, is not straightforward. Even though traditional methods of contact retain power for mobilizing voters, it is their combination with new modes that seems particularly consequential, virtually doubling the estimated impact of traditional contacts alone. This finding boosts the case for parties to adopt new methods into their arsenal of campaign mobilization weapons. However, given that, at least at this point in their development, the newer types of contact target mostly those who have already been contacted through more traditional means, the most likely outcome of an increasing use of digital methods for the foreseeable future would seem to lead to a greater mobilization of the already engaged.

Several limitations of our study must be acknowledged. First, we relied on observational survey data. Although studies based on experimental data are not devoid of the risk of bias in the estimation of the effects of contact on turnout, that risk is much higher with observational data, in spite of the estimation techniques employed in this study. Second, we relied on the self-reports of respondents to measure contact. One might argue that, regardless of the potential slippage between actual exposure to partisan messages and voters' perception of that exposure, it is the latter that should matter to explain voters' behavior. However, we also know that, particularly in what concerns some aspects of online behavior, self-reports and "objective" measures tend to be discrepant (Revilla et al. 2017), and we can only speculate about the potential effects of such discrepancies between perception and reality for our results.

Finally, our analysis of the macro-level determinants of contact, and particularly the null or weak findings for the new forms of contact, may reflect a 'missing variable' problem at the systemic level. On the one hand, internet penetration rates do not necessarily reflect the extent to which online tools are used for political purposes beyond party contacting in different countries, including political discussion, online petitions, chat room participation, e-mail correspondence with candidates, and so on. Such engagement should, in turn, render 
individuals easier to target by parties during political campaigns. Unfortunately, we have no measures of such variables across the broad range of countries under examination in the surveys. On the other hand, our institutional variables fail to capture the new and increasingly broader set of protection and privacy rules that shape parties' micro-targeting efforts, particularly through digital messages. The emerging work on this field has pointed to a relationship between the wider regulatory environment and the incidence of 'data-driven campaigning' in a country (Anstead, 2017; Bennett, 2016). Particular attention has been given to the case of the U.S., a case where much of the privacy regulation that restricts parties and candidates elsewhere is side-stepped (Hersh, 2015; Bennett, 2016; Bimber, 2014). Unfortunately, a comprehensive cross-national picture of these regulatory controls and data protection regimes operating at the national level across CSES countries also does not currently exist. However, there would clearly appear to be an increasingly compelling case for the development and application of such an index in comparative studies of voter mobilization.

Future work departing from this study, besides addressing the preceding limitations, might well take two main directions. First, it is important to confirm and understand how and why the combined effect of traditional and new forms of contacting actually works. Do traditional forms of contacting receive a boost when followed by email, text message or tweets, or vice-versa? Or is the effect simply due to the sheer volume and diversity of contacts? Thus, an important next step for analyses that follow will be to measure the sequencing as well as the frequency of each type of contacting. Second, we have examined the impact of new and traditional forms of contacting on a singular form of participation, namely voting. It may be that social media and other new technologies are already effectively stimulating participation in other ways, such as mobilizing people to become campaign activists, to donate money, or to seek to persuade others to vote. Whether there are stronger or even different effects of these new methods of contact across political participation is clearly an important next question to address.

\section{Acknowledgements}

An earlier version of this article was presented at the World Association for Public Opinion Research (WAPOR) annual conference (2017,Lisbon). We are grateful to the participants at that conference, as well as to the three anonymous reviewers, for their very useful 
comments and suggestions. We would also like to thank Marta Cantijoch, Rosalynd

Southern, and Tobias Konitzer for their help and inputs at the early stages of this project.

\section{References}

Achen, C. H., \& Sinnott, R. (2007). Taking sides: Learning and voting. In Annual Meeting of the Midwest Political Science Association, Chicago, IL.

Aldrich, J. H., Gibson, R. K., Cantijoch, M., \& Konitzer, T. (2016). Getting out the vote in the social media era: Are digital tools changing the extent, nature and impact of party contacting in elections?. Party Politics, 22(2), 165-178.

Anduiza Perea, E (2002). Individual characteristics, institutional incentives and electoral abstention in Western Europe. European Journal of Political Research, 41(5), 643-673.

Anstead, N., (2017). Data-driven campaigning in the 2015 United Kingdom general election. The International Journal of Press/Politics, 22(3): 294-313.

Arceneaux, K. and Nickerson, D.W., 2009. Who is Mobilized to Vote? A Re-analysis of 11 Field Experiments. American Journal of Political Science, 53(1): 1-16.

Bennett, C.J., (2016) Voter databases, micro-targeting, and data protection law: can political parties campaign in Europe as they do in North America?. International Data Privacy Law, 6(4), pp.261-275.

Bhatti, Y., Dahlgaard, J. O., Hansen, J. H., \& Hansen, K. M. (2016). Is door-to-door canvassing effective in Europe? Evidence from a meta-study across six European countries. British Journal of Political Science, 1-12.

Birch, S. (2005). Single-member district electoral systems and democratic transition. Electoral Studies, 24(2), 281-301.

Bimber, B. (2014) Digital media in the Obama campaigns of 2008 and 2012: Adaptation to the personalized political communication environment. Journal of Information Technology \& Politics, 11(2): 130-150.

Blais, A. (2000). To vote or not to vote?: The merits and limits of rational choice theory. Pittsburgh: University of Pittsburgh Press.

Bond et al. 2012 'A 61-million-person experiment in social influence and political mobilization.' Nature 89,295-298.

Bosancianu, C. M. (2014). Online mobilization and offline participation in European elections. GeT MA Working Paper Series, n. 4. 
Boulianne, Shelley. "Social media use and participation: A meta-analysis of current research." Information, Communication \& Society 18, no. 5 (2015): 524-538.

Broockman, D. E., \& Green, D. P. (2014). Do online advertisements increase political candidates' name recognition or favorability? Evidence from randomized field experiments. Political Behavior, 36(2), 263-289.

Cutright, Phillips. 1963. "Measuring the Impact of Local Party Activity on the General Election Vote." Public Opinion Quarterly. 27:372-386.

Cutts, D., Fieldhouse, E., \& John, P. (2009). Is voting habit forming? The longitudinal impact of a GOTV campaign in the UK. Journal of Elections, Public Opinion and Parties, 19(3), 251-263.

Dale, A., \& Strauss, A. (2009). Don't forget to vote: Text message reminders as a mobilization tool. American Journal of Political Science, 53(4), 787-804.

Fieldhouse, E., Cutts, D., Widdop, P., \& John, P. (2013). Do impersonal mobilisation methods work? Evidence from a nationwide Get-Out-the-Vote experiment in England. Electoral Studies, 32(1), 113-123.

Gerber, A. S., Green, D. P., \& Kaplan, E. H. (2004). The illusion of learning from observational research. In I. Shapiro et al. (eds.), Problems and Methods in the Study of Politics. New York: Cambridge University Press.

Gershtenson, J. (2003). Mobilization strategies of the Democrats and Republicans, 1956 2000. Political Research Quarterly, 56(3), 293-308.

Gil de Zúñiga, Homero, Logan Molyneux, Pei Zheng; Social Media, Political Expression, and Political Participation: Panel Analysis of Lagged and Concurrent Relationships, Journal of Communication, Volume 64, Issue 4, 1 August 2014, Pages 612634, https://doi.org/10.1111/icom.12103

Glenn, N. D., \& Grimes, M. (1968). Aging, voting, and political interest. American Sociological Review 33(4): 563-575.

Gosnell, Harold. 1927. Getting out the Vote: An Experiment in the Stimulation of Voting. Chicago: University of Chicago Press.

Green, D. P., \& Gerber, A. S. (2016). Voter Mobilization, Experimentation, and Translational Social Science. Perspectives on Politics, 14(3), 738-749.

Green, D. P \& York, E. A. (2017) Field experiments in political behavior. In J. Fisher et al. (eds.), The Routledge Handbook of Elections, Voting Behavior and Public Opinion. Abdingdon: Routledge. 
Green, D. P., McGrath, M. C., \& Aronow, P. M. (2013). Field experiments and the study of voter turnout. Journal of Elections, Public Opinion \& Parties, 23(1), 27-48.

Hersh, E.D., 2015. Hacking The Electorate: How Campaigns Perceive Voters. Cambridge University Press.

Holt, Kristoffer, Adam Shehata, Jesper Strömbäck, and Elisabet Ljungberg. "Age and the effects of news media attention and social media use on political interest and participation: Do social media function as leveller?." European Journal of Communication 28, no. 1 (2013): 19-34.

Hooghe, M., Vissers, S., Stolle, D., \& Mahéo, V. A. (2010). The potential of Internet mobilization: An experimental study on the effect of Internet and face-to-face mobilization efforts. Political Communication, 27(4), 406-431.

Huckfeldt, R. R., \& Sprague, J. (1995). Citizens, politics and social communication: Information and influence in an election campaign. New York: Cambridge University Press.

John, P., \& Brannan, T. (2008). How different are telephoning and canvassing? Results from a 'get out the vote'field experiment in the British 2005 General Election. British Journal of Political Science, 38(03), 565-574.

Karp, J. A., \& Banducci, S. A. (2007). Party mobilization and political participation in new and old democracies. Party Politics, 13(2), 217-234.

Karp, J. A., Banducci, S. A., \& Bowler, S. (2008). Getting out the vote: Party mobilization in a comparative perspective. British Journal of Political Science,38 (1), 91-112.

Kramer, G. 1971. "The Effects of Precinct Level Canvassing on Voting Behavior." Public Opinion Quarterly. 34:560-572.

Krueger, B. S. (2010). Opt In or Tune Out: Email Mobilization and Political Participation. International Journal of E-Politics (IJEP), 1(4), 55-76.

Maddala, G.S., 1983. Limited-Dependent and Qualitative Variables in Econometrics. Cambridge: Cambridge University Press.

Malhotra, N, Michelson, M. R., Rogers, T. \& Valenzuela, A, A. (2011) Text messages as mobilization tools: the conditional effect of habitual voting and election salience. American Politics Research, 39, pp. 664-681.

Malhotra, N. M., Michelson, M. R. \& Valenzuela, A. A. (2012) Emails from official sources can increase turnout. Quarterly Journal of Political Science, 7, pp. 321-332.

Milbrath, L. (1965). Political participation. Chicago: Rand McNally. 
Magalhães, Pedro C. (2016). "Mobilization, Informal Networks and the Social Contexts of Turnout," with Paolo Segatti and Tianjian Shi, in Paul A. Beck, Richard Gunther, Pedro C. Magalhães, and Alejandro Moreno (eds.), Voting in Old and New Democracies. Milton Park: Routledge.

Merriam, C. E., \& Gosnell, H. F. (1924). Non-voting. University Press.

Nickerson, D. W. (2006). Hunting the elusive young voter. Journal of Political Marketing, 5(3), 47-69.

Nickerson, D. W. (2007). Does email boost turnout?. Quarterly Journal of Political Science, 2(4), 369-380.

Nyman, P. (2017). Door-to-door canvassing in the European elections: Evidence from a Swedish field experiment. Electoral Studies, 45, 110-118.

Panagopoulos, C., 2016. All about that base: Changing campaign strategies in US presidential elections. Party Politics, 22(2): 179-190.

Panagopoulos, Costas \& Peter L. Francia (2009), «Grassroots Mobilization in the 2008 Presidential Election». Journal of Political Marketing, 8:315-333.

Powell Jr, G. B. (1986). American voter turnout in comparative perspective. The American Political Science Review, 17-43.

Putnam, R. D. (2001). Bowling alone: The collapse and revival of American community. New York: Simon and Schuster

Revilla, M., Ochoa, C., \& Loewe, G. (2017). Using passive data from a meter to complement survey data in order to study online behavior. Social Science Computer Review, 35(4), 521-536.

Rosenstone and Hansen. 1993. Mobilization, Participation, and Democracy in America. MacMillan: New York.

Shaffer, S. D. (1981). A multivariate explanation of decreasing turnout in presidential elections, 1960-1976. American Journal of Political Science 25(1): 68-95.

Shirky, Clay. "The political power of social media: Technology, the public sphere, and political change." Foreign affairs (2011): 28-41.

Stevens, Daniel, and Benjamin G. Bishin. 2011. "Getting Out the Vote: Minority Mobilization in a Presidential Election." Political Behavior 33 (1): 113-138.

Strate, J. M., Parrish, C. J., Elder, C. D., \& Ford, C. (1989). Life span civic development and voting participation. American Political Science Review, 83(2), 443-464. 
Stollwerk, A. F. (2006). Does e-mail affect voter turnout? An experimental study of the New York City 2005 election. Unpublished Manuscript. Institution for Social and Policy Studies, Yale University. http://gotv. research. yale. edu.

Vaccari, C. (2017). Online mobilization in comparative perspective: Digital appeals and political engagement in Germany, Italy, and the United Kingdom. Political Communication, 34(1), 69-88.

Verba, S., Schlozman, K. L., \& Brady, H. E. (1995). Voice and equality: Civic voluntarism in American politics. Cambridge: Harvard University Press.

Wilde, J. (2000). Identification of multiple equation probit models with endogenous dummy regressors. Economics letters, 69(3), 309-312.

\section{Author biography}

Pedro C. Magalhães is Principal Researcher at the Institute of Social Sciences of the University of Lisbon. John H. Aldrich is the Pfizer-Pratt University Professor of Political Science, Duke University. Rachel K. Gibson is Professor of Political Science and the University of Manchester and Director of the Cathie Marsh Institute for Social Research. 
Figure 1. Prevalence of different types of party contacting (\%)

Mail/leaflet

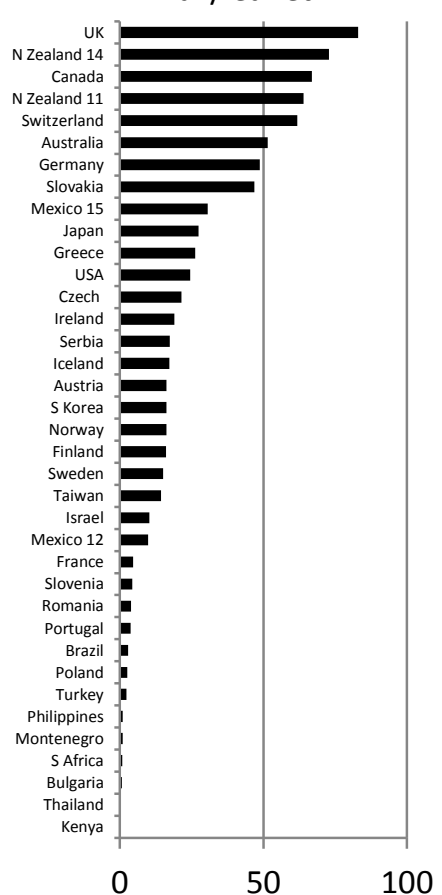

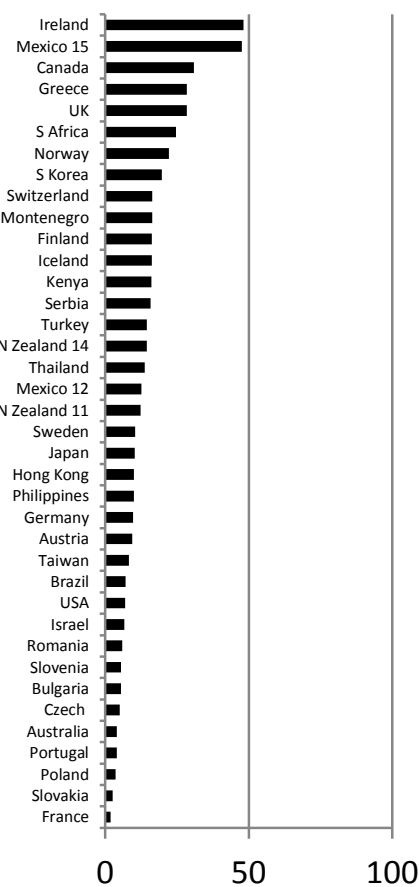

Face to face

Phone

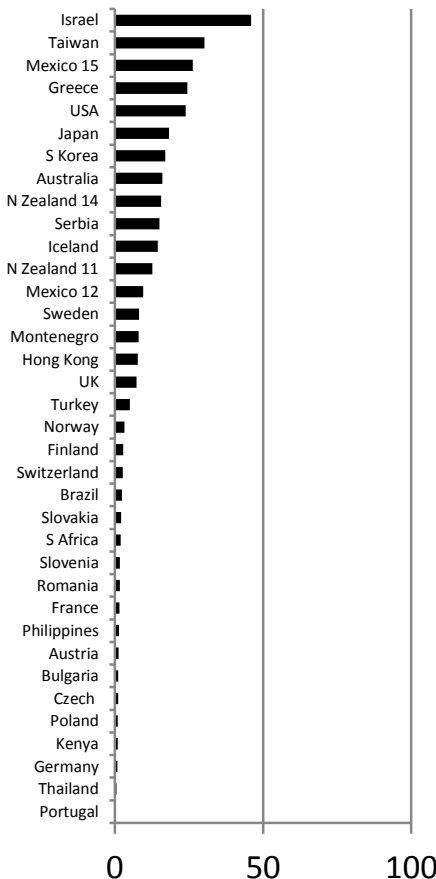

Social network

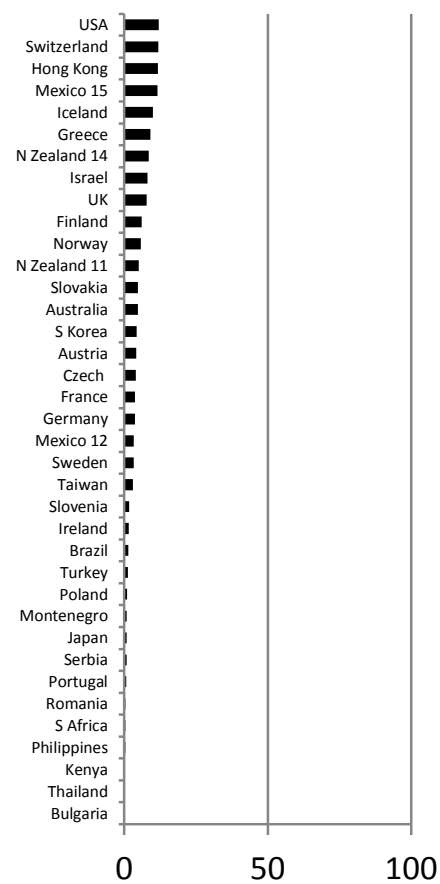

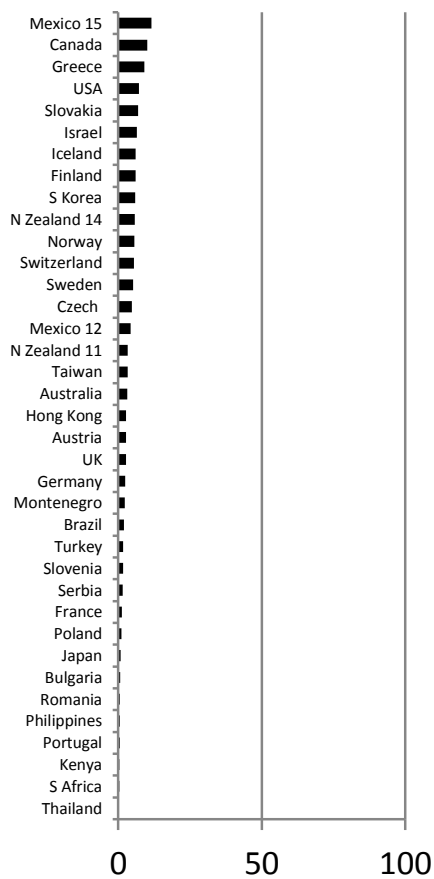


Figure 2. Percentage of respondents contacted by parties or candidates in traditional, new, or any ways.

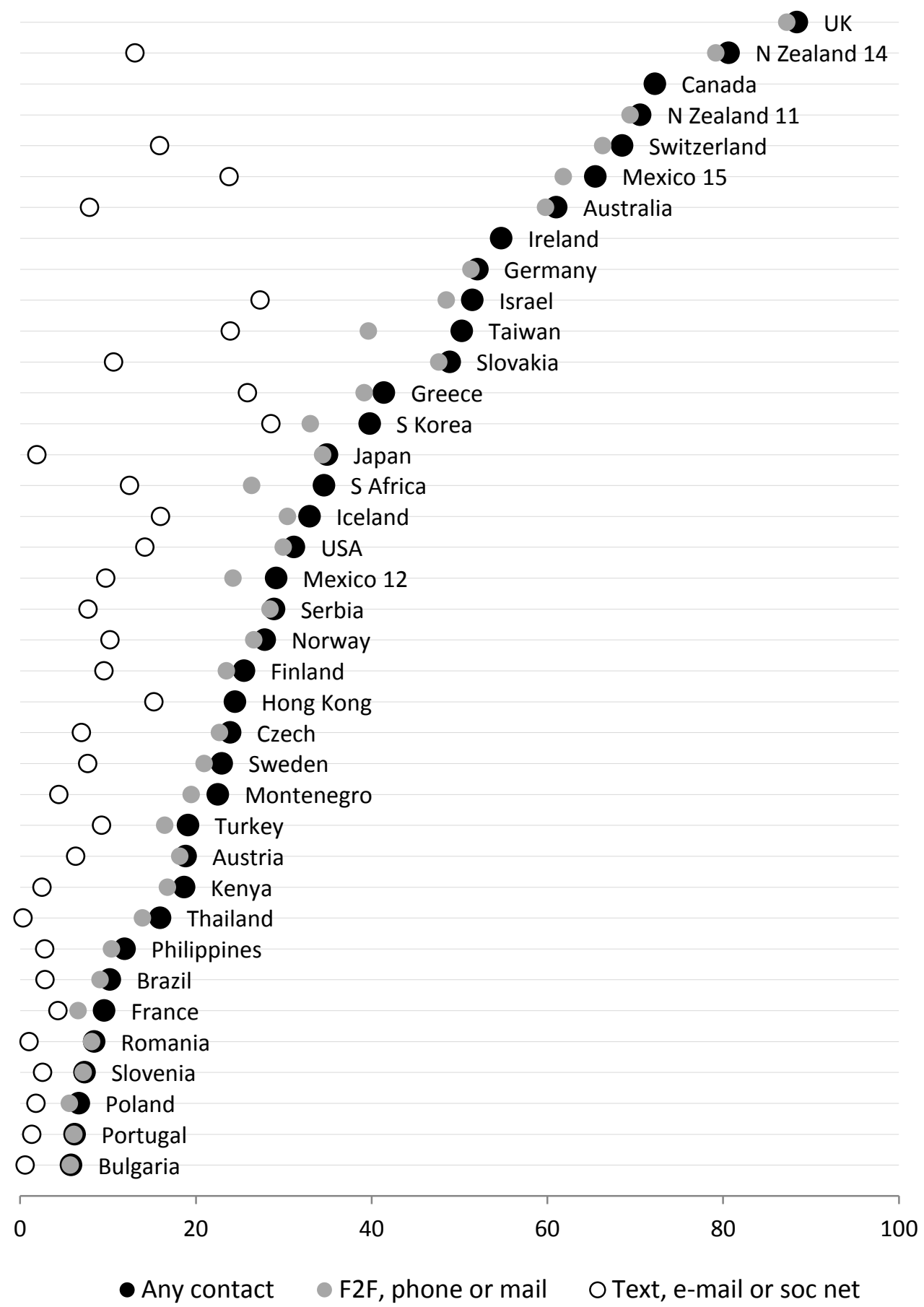


Figure 3. Percentage of respondents reporting different combinations of contacts by parties or candidates.

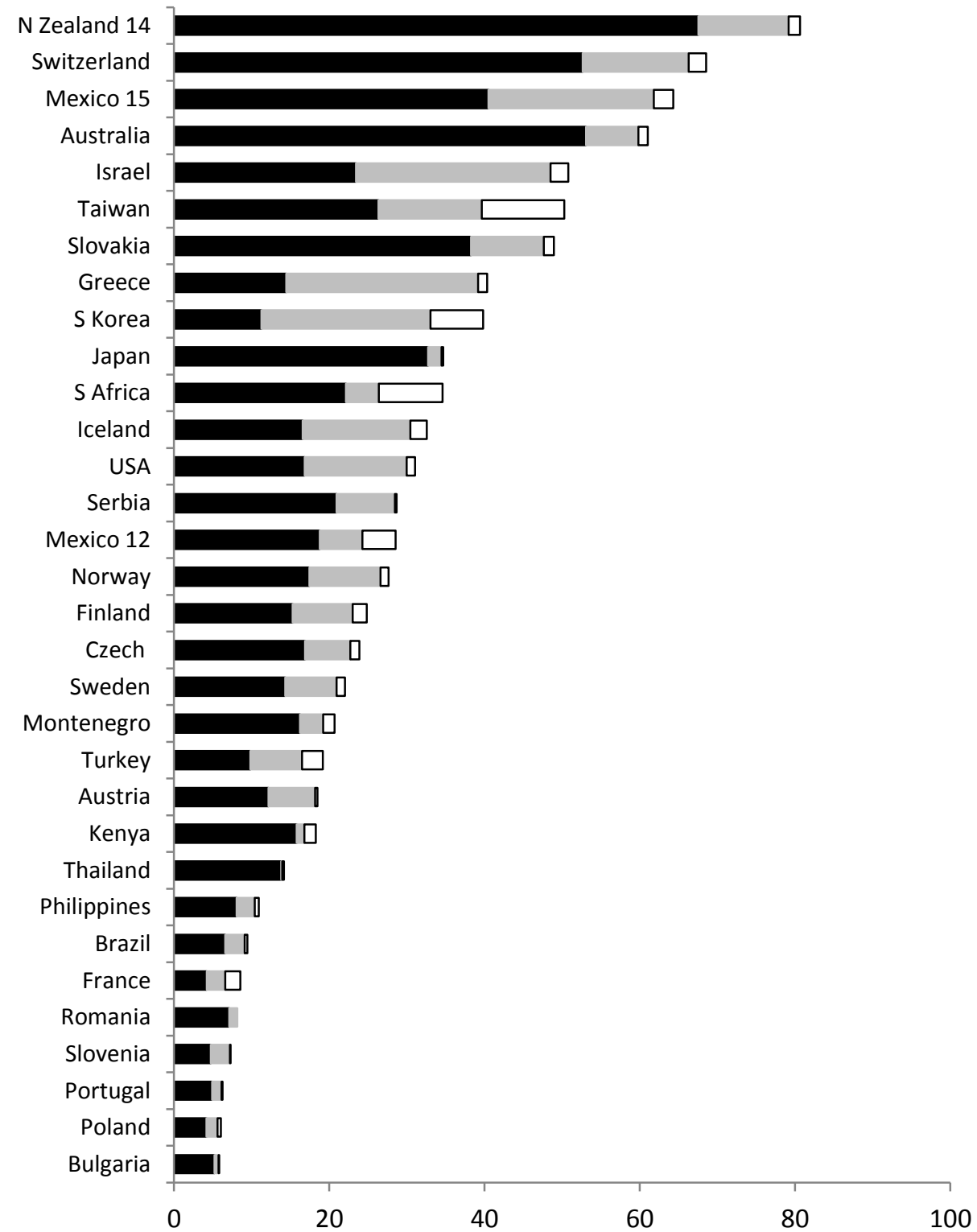

- Just F2F, mail or phone Both $\square$ Just text, e-mail or soc net 
Figure 4. Predicted probability of being contacted in different ways, by age of respondent. Multilevel logistic regression, 32 countries.

Face to face contact

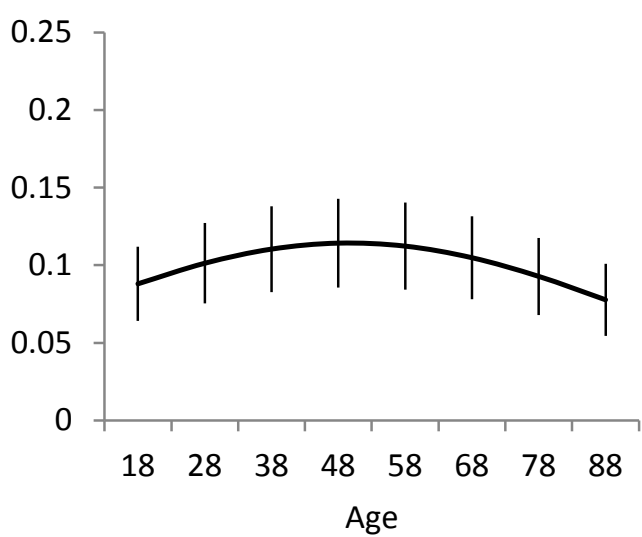

E-mail contact

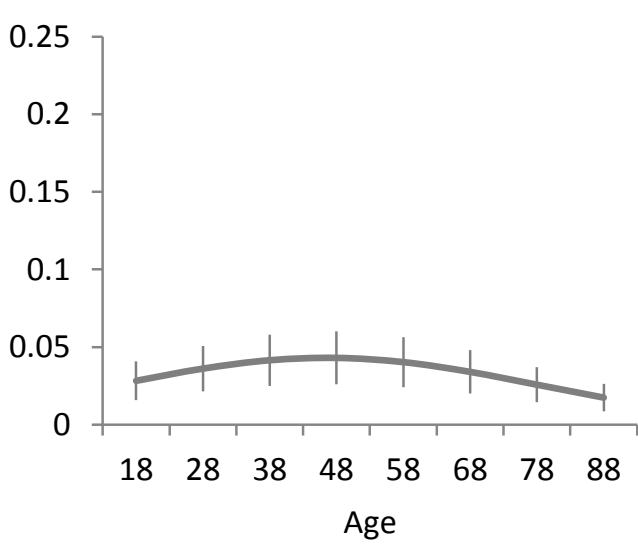

Mail contact

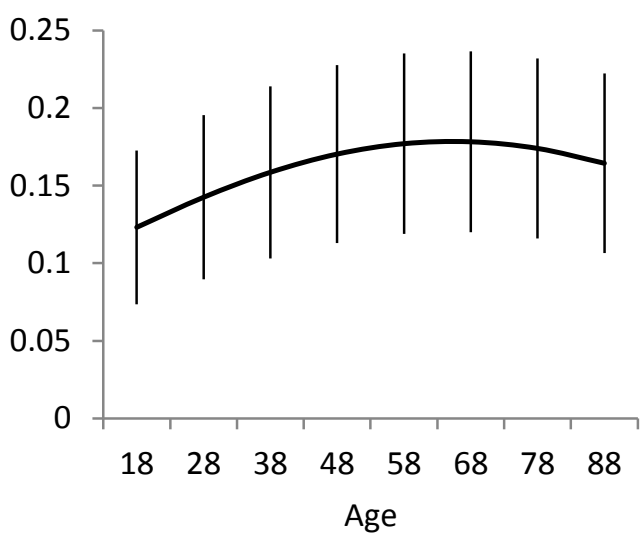

Text/SMS contact

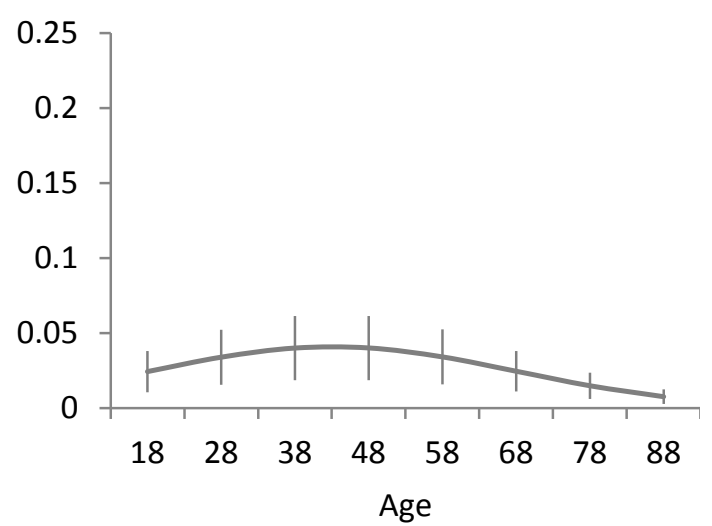

Phone contact

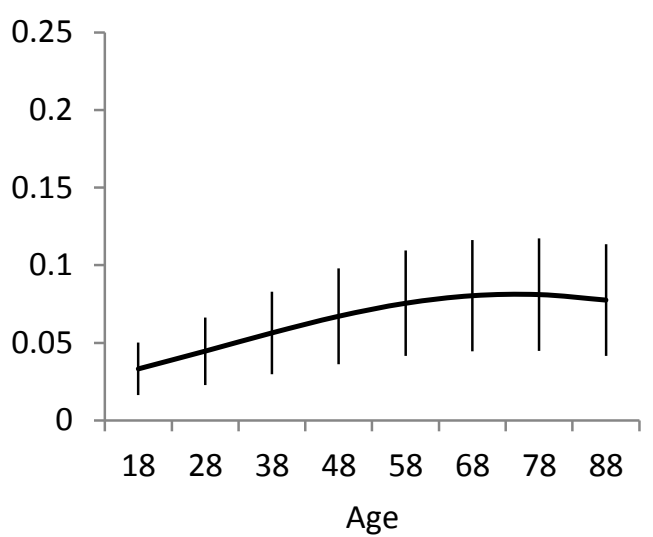

Social network contact

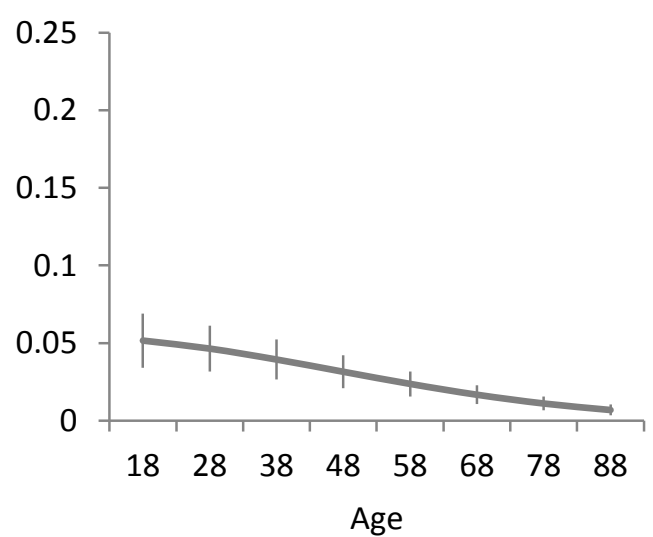


Figure 5. Predicted probability of being contacted in any way, by traditional means or by new means, depending on age of respondent. Multilevel logistic regression, 32 countries.

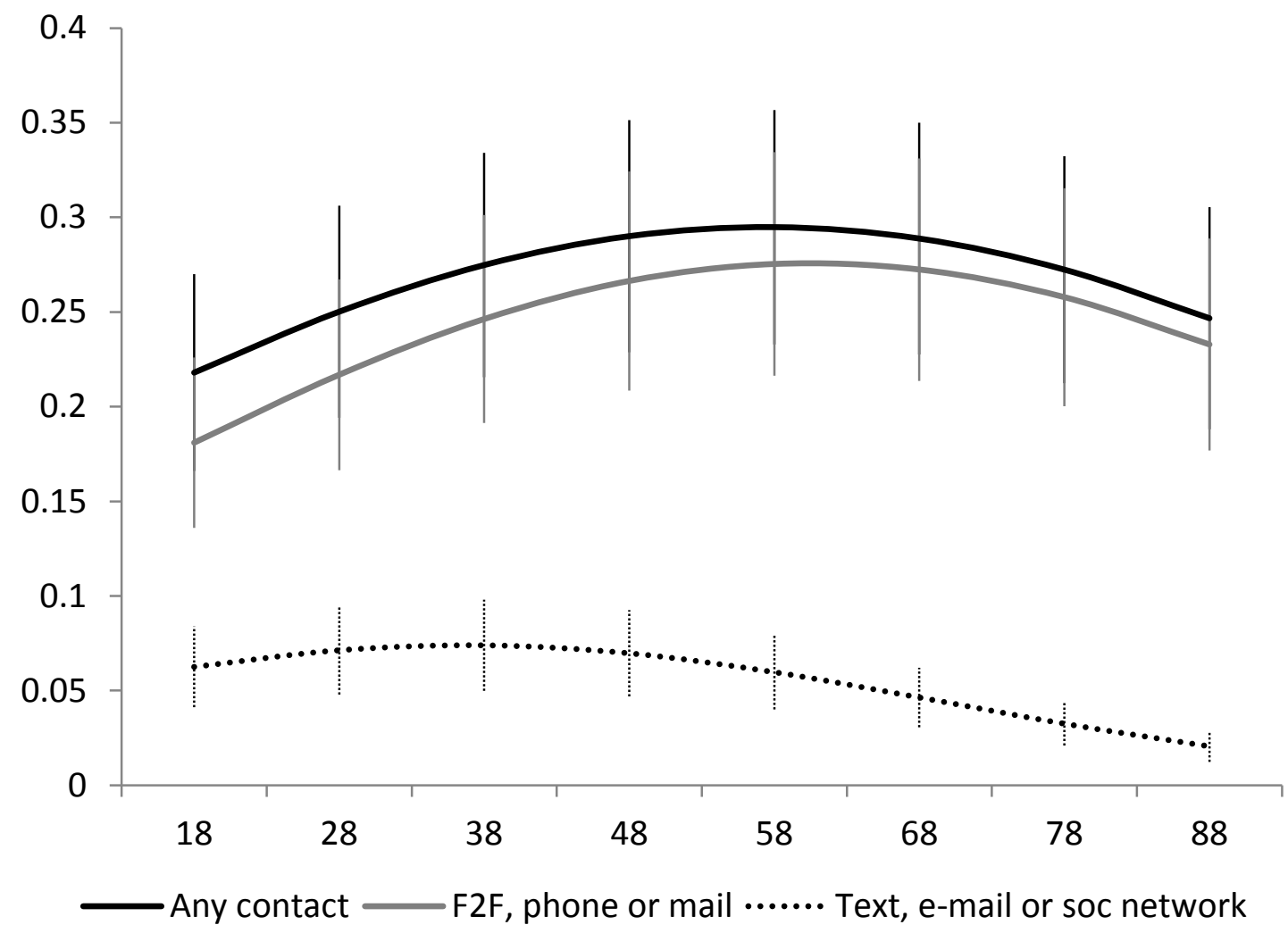


Figure 6. Marginal effects of contact on the probability of turning out to vote $(95 \% \mathrm{Cl})$

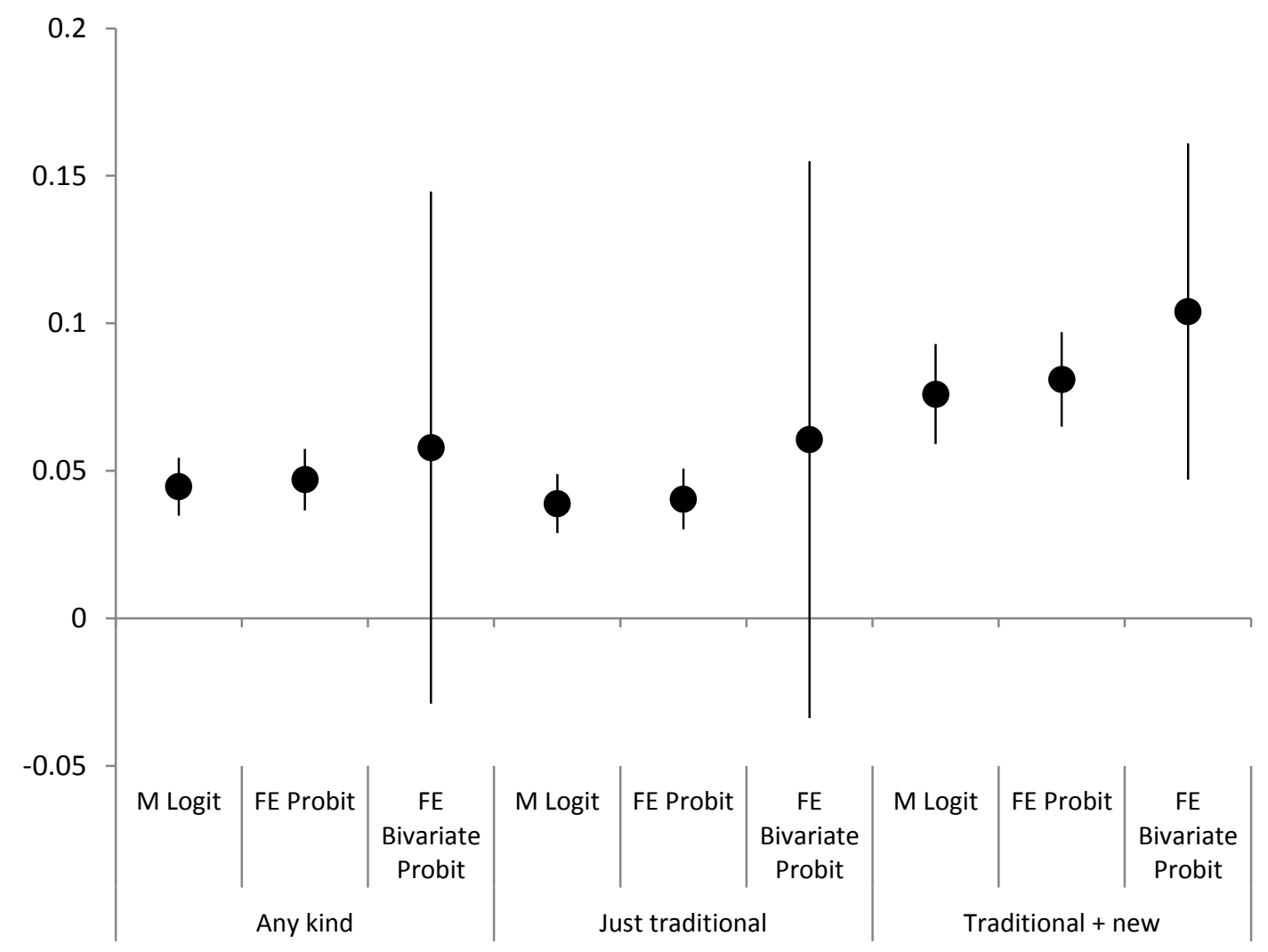


Table 1. Aggregate level correlations between prevalence of different types of party contacting and a selection of macro-level variables.

\begin{tabular}{|c|c|c|c|c|c|c|c|c|c|}
\hline & $\begin{array}{l}\text { Face } \\
\text { to } \\
\text { face }\end{array}$ & Mail & Phone & Text & E-mail & $\begin{array}{l}\text { Social } \\
\text { nets }\end{array}$ & $\begin{array}{l}\text { Tradi- } \\
\text { tional }\end{array}$ & New & Any \\
\hline $\begin{array}{l}\text { Use of winner } \\
\text { take all rules }\end{array}$ & .00 & .33 & .13 & .03 & .13 & .04 & .29 & .05 & .28 \\
\hline Use of SMD's & .16 & .48 & .31 & .18 & .25 & .17 & .52 & .25 & .51 \\
\hline $\begin{array}{c}\text { Age of } \\
\text { democracy (log) }\end{array}$ & .10 & .61 & .20 & .00 & .31 & .37 & .50 & .18 & .48 \\
\hline $\begin{array}{l}\text { Party system } \\
\text { polarization }\end{array}$ & -.07 & .25 & -.11 & .02 & .28 & .24 & .13 & .14 & .10 \\
\hline $\begin{array}{l}\text { GDP per capita } \\
\text { (log) }\end{array}$ & .04 & .49 & .15 & -.01 & .57 & .37 & .38 & .33 & .38 \\
\hline $\begin{array}{c}\text { Internet } \\
\text { penetration }\end{array}$ & & & & .05 & .48 & .29 & & .29 & \\
\hline $\begin{array}{c}\text { Mobile } \\
\text { subscriptions }\end{array}$ & & & & -.02 & .19 & -.11 & & .07 & \\
\hline
\end{tabular}


Table 2. Correlates of party mobilization. Multilevel logistic regression standardized coefficients.

\begin{tabular}{|c|c|c|c|c|c|c|}
\hline & \multicolumn{3}{|c|}{ Traditional } & \multicolumn{3}{|c|}{ New } \\
\hline & $\begin{array}{l}\text { Face to } \\
\text { face }\end{array}$ & Mail & Phone & Texting & E-mail & $\begin{array}{c}\text { Social } \\
\text { network }\end{array}$ \\
\hline Age of democracy (log) & $\begin{array}{l}.10 \\
(.32)\end{array}$ & $\begin{array}{l}1.30^{*} \\
(.56)\end{array}$ & $\begin{array}{l}.34 \\
(.47)\end{array}$ & $\begin{array}{l}.25 \\
(.54)\end{array}$ & $\begin{array}{l}.02 \\
(.40)\end{array}$ & $\begin{array}{l}.23 \\
(.34)\end{array}$ \\
\hline Single member districts & $\begin{array}{l}.34 \\
(.29)\end{array}$ & $\begin{array}{c}1.14^{* *} \\
(.38)\end{array}$ & $\begin{array}{l}.99 * \\
(.43)\end{array}$ & $\begin{array}{l}.35 \\
(.55)\end{array}$ & $\begin{array}{l}.44 \\
(.32)\end{array}$ & $\begin{array}{l}.18 \\
(.27)\end{array}$ \\
\hline GDP per capita, 000s (log) & $\begin{array}{l}-.25 \\
(.31)\end{array}$ & $\begin{array}{c}1.70 * * \\
(.51)\end{array}$ & $\begin{array}{l}.30 \\
(.46)\end{array}$ & - & - & - \\
\hline $\begin{array}{l}\text { Mobile phone subscriptions } \\
\text { (per hundred) }\end{array}$ & - & - & - & $\begin{array}{l}.12 \\
(.48)\end{array}$ & - & - \\
\hline Internet penetration rate & - & - & - & - & $\begin{array}{c}1.27 * * \\
(.41)\end{array}$ & $\begin{array}{l}.74^{*} \\
(.35)\end{array}$ \\
\hline Female & $\begin{array}{c}-.11 * * * \\
(.03)\end{array}$ & $\begin{array}{l}.06^{*} \\
(.02)\end{array}$ & $\begin{array}{l}.08^{*} \\
(.03)\end{array}$ & $\begin{array}{c}-.14 * * * \\
(.04)\end{array}$ & $\begin{array}{c}-.25 * * * \\
(.04)\end{array}$ & $\begin{array}{c}-.21 * * * \\
(.05)\end{array}$ \\
\hline Age & $\begin{array}{c}.99 * * * \\
(.17)\end{array}$ & $\begin{array}{c}1.07 * * * \\
(.15)\end{array}$ & $\begin{array}{c}1.60 * * * \\
(.20)\end{array}$ & $\begin{array}{c}2.54 * * * \\
(.31)\end{array}$ & $\begin{array}{c}1.34^{* * * *} \\
(.29)\end{array}$ & $\begin{array}{l}-.45 \\
(.31)\end{array}$ \\
\hline Age squared & $\begin{array}{c}-.35^{* * *} \\
(.06)\end{array}$ & $\begin{array}{c}-.30 * * * \\
(.05)\end{array}$ & $\begin{array}{c}-.38^{* * *} \\
(.07)\end{array}$ & $\begin{array}{c}-1.03 * * * \\
(.11)\end{array}$ & $\begin{array}{c}-.54 * * * \\
(.10)\end{array}$ & $\begin{array}{l}-.17 \\
(.12)\end{array}$ \\
\hline Education & $\begin{array}{l}.26 * * * \\
(.04)\end{array}$ & $\begin{array}{c}.47^{* * *} \\
(.03)\end{array}$ & $\begin{array}{c}.45^{* * *} \\
(.04)\end{array}$ & $\begin{array}{l}.71^{* *} \\
(.05)\end{array}$ & $\begin{array}{c}1.07 * * * \\
(.05)\end{array}$ & $\begin{array}{l}.87^{* * *} \\
(.06)\end{array}$ \\
\hline Married & $\begin{array}{l}.05 \\
(.03)\end{array}$ & $\begin{array}{c}.12^{* * *} \\
(.03)\end{array}$ & $\begin{array}{c}.16^{* * *} \\
(.04)\end{array}$ & $\begin{array}{l}.12 * \\
(.05)\end{array}$ & $\begin{array}{r}-.001 \\
(.05)\end{array}$ & $\begin{array}{l}-.12^{*} \\
(.05)\end{array}$ \\
\hline Close to party & $\begin{array}{c}.62^{* * *} \\
(.90)\end{array}$ & $\begin{array}{c}.41 * * * \\
(.03)\end{array}$ & $\begin{array}{c}.44 * * * \\
(.03)\end{array}$ & $\begin{array}{c}.53 * * * \\
(.04)\end{array}$ & $\begin{array}{c}.74^{* * *} \\
(.05)\end{array}$ & $\begin{array}{c}.69 * * * \\
(.05)\end{array}$ \\
\hline Constant & $\begin{array}{c}-2.83 * * * \\
(.77) \\
\end{array}$ & $\begin{array}{c}-10.80^{* * *} \\
(1.04) \\
\end{array}$ & $\begin{array}{c}-6.99 * * * \\
(1.13) \\
\end{array}$ & $\begin{array}{c}-6.71 * * * \\
(1.77) \\
\end{array}$ & $\begin{array}{c}-8.56 * * * \\
(.67) \\
\end{array}$ & $\begin{array}{c}-5.82 * * * \\
(.57) \\
\end{array}$ \\
\hline $\begin{array}{l}\text { Random intercept } \\
\text { parameter } \\
\text { Country/election variance }\end{array}$ & .75 & 1.19 & 1.56 & 1.93 & .82 & .58 \\
\hline Countries/elections & 38 & 37 & 36 & 34 & 37 & 37 \\
\hline Respondents & 55,830 & 54,922 & 53,085 & 50,192 & 54,759 & 54,153 \\
\hline
\end{tabular}


Table 3. Correlates of party mobilization. Multilevel logistic regression standardized coefficients.

\begin{tabular}{|c|c|c|c|}
\hline & \multicolumn{3}{|c|}{ Multilevel logistic } \\
\hline & Any contact & Traditional & New \\
\hline \multirow[t]{2}{*}{ Age of democracy (log) } & .43 & .50 & .62 \\
\hline & $(.41)$ & $(.41)$ & $(.50)$ \\
\hline \multirow[t]{2}{*}{ Single member districts } & $1.08^{* * *}$ & $1.03^{* * *}$ & .37 \\
\hline & $(.32)$ & $(.32)$ & $(.38)$ \\
\hline \multirow[t]{2}{*}{ GDP per capita, 000s (log) } & .26 & .25 & .31 \\
\hline & (.39) & $(.38)$ & $(.46)$ \\
\hline \multirow[t]{2}{*}{ Female } & -.01 & .01 & $-.18 * * *$ \\
\hline & $(.02)$ & $(.02)$ & $(.03)$ \\
\hline \multirow[t]{2}{*}{ Age } & $1.05^{* * *}$ & $1.27^{* * *}$ & $1.31^{* * *}$ \\
\hline & $(.14)$ & $(.14)$ & $(. .22)$ \\
\hline \multirow[t]{2}{*}{ Age squared } & $-.32 * * *$ & $-.37 * * *$ & $-.62 * * *$ \\
\hline & $(. .05)$ & $(. .05)$ & $(.08)$ \\
\hline \multirow[t]{2}{*}{ Education } & $.47 * * *$ & $.40 * * *$ & $.83^{* * *}$ \\
\hline & $(.03)$ & $(.03)$ & $(.04)$ \\
\hline \multirow[t]{2}{*}{ Married } & $.06 * *$ & $.06 * *$ & .04 \\
\hline & $(.03)$ & $(.03)$ & $(.04)$ \\
\hline \multirow[t]{2}{*}{ Close to party } & $.59 * * *$ & $.57 * * *$ & $.65 * * *$ \\
\hline & $(.02)$ & $(.02)$ & $(.04)$ \\
\hline \multirow[t]{2}{*}{ Constant } & $-4.30 * * *$ & $-4.65 * * *$ & $-6.26 * * *$ \\
\hline & $(.78)$ & $(.78)$ & $(.93)$ \\
\hline \multicolumn{4}{|l|}{ Random intercept parameter } \\
\hline Country/election variance & .72 & .71 & .98 \\
\hline Countries/elections & & 32 & \\
\hline Respondents & & 47,609 & \\
\hline
\end{tabular}

${ }^{*} \mathrm{p}<.05 ;{ }^{* *} \mathrm{p}<.01 ; * * * \mathrm{p}>.001$ 
Table 4. Estimates of the effect of different types of contact: multilevel logistic, fixed-effects probit and fixed-effects bivariate probit. Standardized coefficients.

\begin{tabular}{|c|c|c|c|c|c|c|c|c|c|c|c|c|}
\hline \multirow[b]{3}{*}{ Dependent variable } & \multicolumn{4}{|c|}{ Any contact } & \multicolumn{4}{|c|}{ Just traditional contact } & \multicolumn{4}{|c|}{ Traditional + new contact } \\
\hline & \multirow{2}{*}{$\begin{array}{c}\begin{array}{c}\text { Multilevel } \\
\text { logistic }\end{array} \\
\text { Turnout }\end{array}$} & \multirow{2}{*}{$\begin{array}{c}\begin{array}{l}\text { Fixed- } \\
\text { effects } \\
\text { probit }\end{array} \\
\text { Turnout } \\
\end{array}$} & \multicolumn{2}{|c|}{$\begin{array}{l}\text { Bivariate fixed-effects } \\
\text { probit }\end{array}$} & \multirow{2}{*}{$\begin{array}{c}\begin{array}{c}\text { Multilevel } \\
\text { logistic }\end{array} \\
\text { Turnout }\end{array}$} & \multirow{2}{*}{$\begin{array}{c}\begin{array}{l}\text { Fixed- } \\
\text { effects } \\
\text { probit }\end{array} \\
\text { Turnout }\end{array}$} & \multicolumn{2}{|c|}{$\begin{array}{l}\text { Bivariate fixed-effects } \\
\text { probit }\end{array}$} & \multirow{2}{*}{$\begin{array}{c}\begin{array}{c}\text { Multilevel } \\
\text { logistic }\end{array} \\
\text { Turnout }\end{array}$} & \multirow{2}{*}{$\begin{array}{c}\begin{array}{l}\text { Fixed- } \\
\text { effects } \\
\text { probit }\end{array} \\
\text { Turnout }\end{array}$} & \multicolumn{2}{|c|}{$\begin{array}{l}\text { Bivariate fixed-effects } \\
\text { probit }\end{array}$} \\
\hline & & & Turnout & Contact & & & Turnout & Contact & & & Turnout & Contact \\
\hline Compulsory voting & $\begin{array}{l}.98^{* *} \\
(.30)\end{array}$ & - & - & - & $\begin{array}{l}.98^{* *} \\
(.31)\end{array}$ & - & - & - & $\begin{array}{l}.98^{* *} \\
(.32)\end{array}$ & - & - & - \\
\hline Female & $\begin{array}{l}.005 \\
(.03)\end{array}$ & $\begin{array}{l}.007 \\
(.02)\end{array}$ & - & - & $\begin{array}{r}-.002 \\
(.03)\end{array}$ & $\begin{array}{l}.003 \\
(.02)\end{array}$ & - & - & $\begin{array}{l}.001 \\
(.03)\end{array}$ & $\begin{array}{c}01 \\
(.02)\end{array}$ & - & $\begin{array}{l}-.07^{*} \\
(.03)\end{array}$ \\
\hline Age & $\begin{array}{c}1.76^{* * *} \\
(.16)\end{array}$ & $\begin{array}{c}1.03 * * * \\
(.18)\end{array}$ & $\begin{array}{c}1.02 * * * \\
(.18)\end{array}$ & $\begin{array}{c}.64 * * * \\
(.13)\end{array}$ & $\begin{array}{c}1.74 * * * \\
(.16)\end{array}$ & $\begin{array}{c}1.01 * * * \\
(.18)\end{array}$ & $\begin{array}{l}.99 * * * \\
(.19)\end{array}$ & $\begin{array}{c}.71^{* * *} \\
(.11)\end{array}$ & $\begin{array}{c}1.92 * * * \\
(.18)\end{array}$ & $\begin{array}{c}1.12^{* * *} \\
(.16)\end{array}$ & $\begin{array}{c}1.11^{* * *} \\
(.15)\end{array}$ & $\begin{array}{c}1.08^{* * *} \\
(.27)\end{array}$ \\
\hline Age squared & $\begin{array}{c}-.42^{* * *} \\
(.06)\end{array}$ & $\begin{array}{c}-.25^{* * *} \\
(.06)\end{array}$ & $\begin{array}{c}-.25^{* * *} \\
(.06)\end{array}$ & $\begin{array}{c}-.20^{* * *} \\
(.04)\end{array}$ & $\begin{array}{c}-.41 * * * \\
(.06)\end{array}$ & $\begin{array}{c}-.25 * * * \\
(.07)\end{array}$ & $\begin{array}{c}-.24 * * * \\
(.06)\end{array}$ & $\begin{array}{c}-.18^{* * *} \\
(.04)\end{array}$ & $\begin{array}{c}-.48^{* * *} \\
(.06)\end{array}$ & $\begin{array}{l}.29 * * * \\
(.06)\end{array}$ & $\begin{array}{c}-.28^{* * *} \\
(.05)\end{array}$ & $\begin{array}{c}-.45^{* * *} \\
(.09)\end{array}$ \\
\hline Education & $\begin{array}{c}.65^{* * *} \\
(.04)\end{array}$ & $\begin{array}{l}.34 * * * \\
(.04)\end{array}$ & $\begin{array}{l}.34 * * * \\
(.05)\end{array}$ & $\begin{array}{l}.28 * * * \\
(.03)\end{array}$ & $\begin{array}{l}.64 * * * \\
(.04)\end{array}$ & $\begin{array}{c}.34 * * * \\
(.04)\end{array}$ & $\begin{array}{l}.34 * * * \\
(.05)\end{array}$ & $\begin{array}{l}.14^{* * *} \\
(.03)\end{array}$ & $\begin{array}{l}.66 * * * \\
(.04)\end{array}$ & $\begin{array}{l}.35 * * * \\
(.05)\end{array}$ & $\begin{array}{l}.34 * * * \\
(.04)\end{array}$ & $\begin{array}{l}.46 * * * \\
(.05)\end{array}$ \\
\hline Married & $\begin{array}{c}.37^{* * *} \\
(.03)\end{array}$ & $\begin{array}{l}.21 * * * \\
(.02)\end{array}$ & $\begin{array}{l}.21 * * * \\
(.02)\end{array}$ & - & $\begin{array}{c}.36 * * * \\
(.03)\end{array}$ & $\begin{array}{l}.21^{* * *} \\
(.02)\end{array}$ & $\begin{array}{c}.20 * * * \\
(.02)\end{array}$ & - & $\begin{array}{l}.36 * * * \\
(.03)\end{array}$ & $\begin{array}{l}.21^{* * *} \\
(.02)\end{array}$ & $\begin{array}{l}.21 * * * \\
(.02)\end{array}$ & - \\
\hline Close to party & $\begin{array}{c}1.12^{* * *} \\
(.03)\end{array}$ & $\begin{array}{l}.60 * * * \\
(.05)\end{array}$ & $\begin{array}{l}.59 * * * \\
(.07)\end{array}$ & $\begin{array}{l}.34 * * * \\
(.03)\end{array}$ & $\begin{array}{c}1.11 * * * \\
(.03)\end{array}$ & $\begin{array}{l}.59 * * * \\
(-05)\end{array}$ & $\begin{array}{l}.59 * * * \\
(.07)\end{array}$ & $\begin{array}{l}.27^{* * *} \\
(.04)\end{array}$ & $\begin{array}{c}1.08 * * * \\
(.04)\end{array}$ & $\begin{array}{l}.58 * * * \\
(.05)\end{array}$ & $\begin{array}{l}.57 * * * \\
(.06)\end{array}$ & $\begin{array}{c}.45 \\
(.04)^{* * *}\end{array}$ \\
\hline Any contact & $\begin{array}{c}.46 * * * \\
(.04)\end{array}$ & $\begin{array}{l}.25 * * * \\
(.03)\end{array}$ & $\begin{array}{c}.31 \\
(.25)\end{array}$ & - & - & - & - & - & - & - & - & - \\
\hline Traditional contact & - & - & - & - & $\begin{array}{l}.39 * * * \\
(.04)\end{array}$ & $\begin{array}{l}.21 * * * \\
(.03)\end{array}$ & $\begin{array}{l}.32 \\
(.28)\end{array}$ & - & - & - & - & - \\
\hline $\begin{array}{l}\text { Traditional + new } \\
\text { contact }\end{array}$ & - & - & - & - & - & - & - & - & $\begin{array}{l}.84^{* * *} \\
(.07)\end{array}$ & $\begin{array}{l}.45 * * * \\
(.06)\end{array}$ & $\begin{array}{l}.61^{* *} \\
(.22)\end{array}$ & - \\
\hline Constant & $\begin{array}{c}-1.14 * * * \\
(.17) \\
\end{array}$ & $\begin{array}{l}-.04 \\
(.12) \\
\end{array}$ & $\begin{array}{l}-.05 \\
(.13) \\
\end{array}$ & $\begin{array}{c}-.91 * * * \\
(.14) \\
\end{array}$ & $\begin{array}{c}-1.10^{* * *} \\
(.18) \\
\end{array}$ & $\begin{array}{l}.00 \\
(.13) \\
\end{array}$ & $\begin{array}{l}-.03 \\
(.14) \\
\end{array}$ & - & $\begin{array}{l}-1.24 \\
(.18) \\
\end{array}$ & $\begin{array}{c}-.89 * * * \\
(.10) \\
\end{array}$ & $\begin{array}{c}-.89 * * * \\
(.10) \\
\end{array}$ & $\begin{array}{c}-2.35^{* * *} \\
(.22) \\
\end{array}$ \\
\hline $\begin{array}{l}\text { Random intercept } \\
\text { parameter } \\
\text { Country/election } \\
\text { variance }\end{array}$ & $.48^{* *}$ & & & & $.49 * *$ & & & & $.51^{* *}$ & & & \\
\hline rho & & & & & & & & & - & - & & \\
\hline $\begin{array}{l}\text { Countries/elections } \\
\text { Respondents }\end{array}$ & \multicolumn{4}{|c|}{$\begin{array}{c}32 \\
46,735\end{array}$} & \multicolumn{4}{|c|}{$\begin{array}{c}32 \\
42,475 \\
\end{array}$} & \multicolumn{4}{|c|}{$\begin{array}{c}32 \\
35,972\end{array}$} \\
\hline
\end{tabular}

${ }^{*} p<.05 ; * * p<.01 ; * * * p>.001$ 
ONLINE APPENDIX:

\section{Variables and sources}

\begin{tabular}{|c|c|}
\hline Variable & Source \\
\hline Mail/leaflet contact & CSES 4 (April 2017 Release): Variable D3020_2 \\
\hline Face to face contact & CSES 4 (April 2017 Release): Variable D3020_1 \\
\hline Phone contact & CSES 4 (April 2017 Release): Variable D3020_3 \\
\hline Text/SMS contact & CSES 4 (April 2017 Release): Variable D3020_4 \\
\hline E-mail contact & CSES 4 (April 2017 Release): Variable D3020_5 \\
\hline Social network contact & CSES 4 (April 2017 Release): Variable D3020_6 \\
\hline Female & CSES 4 (April 2017 Release): Variable D2002 \\
\hline Age & CSES 4 (April 2017 Release): Variable D2001_Y \\
\hline Education & CSES 4 (April 2017 Release): Variable D2003 \\
\hline Married & CSES 4 (April 2017 Release): Variable D2004 \\
\hline Close to party & CSES 4 (April 2017 Release): Variable D3018_1 \\
\hline Age of democracy (log) & $\begin{array}{l}\text { Polity IV dataset (Available at: } \\
\text { http://www.systemicpeace.org/inscrdata.html). }\end{array}$ \\
\hline Single member districts & $\begin{array}{l}\text { Cruz, Keeter, and Scartascini (2016). Available at: } \\
\text { http://www.iadb.org/en/research-and-data/publication- } \\
\text { details,3169.html?pub_id=IDB-DB-121. }\end{array}$ \\
\hline $\begin{array}{l}\text { GDP per capita 000s } \\
\text { (log) }\end{array}$ & $\begin{array}{l}\text { GDP per capita PPP at constant } 2011 \text { international dollars, from the World } \\
\text { Bank (Available at: } \\
\text { http://data.worldbank.org/indicator/NY.GDP.PCAP.PP.KD) . }\end{array}$ \\
\hline $\begin{array}{l}\text { Mobile phone } \\
\text { subscriptions }\end{array}$ & Available at: http://data.worldbank.org/indicator/IT.CEL.SETS.P2. \\
\hline $\begin{array}{l}\text { Internet penetration } \\
\text { rate }\end{array}$ & Available at: http://data.worldbank.org/indicator/IT.NET.USER.ZS. \\
\hline Winner take all & $\begin{array}{l}\text { Cruz, Keeter, and Scartascini (2016). Available at: } \\
\text { http://www.iadb.org/en/research-and-data/publication- } \\
\text { details,3169.html?pub_id=IDB-DB-121. }\end{array}$ \\
\hline $\begin{array}{l}\text { Party system } \\
\text { polarization }\end{array}$ & $\begin{array}{l}\text { See Dalton (2011). Available at: } \\
\text { http://www.cses.org/datacenter/usercommunity3/usercommunity3.htm. }\end{array}$ \\
\hline Compulsory voting & CSES 4 (April 2017 Release): Variable D5044_1 to D5044_4 \\
\hline
\end{tabular}

References:

Cruz, C., Keefer, P. \& Scartascini, C. (2016). Database of Political Institutions Codebook, 2015 Update. Inter-American Development Bank. Updated version of T. Beck, G. Clarke, A. Groff, P. Keefer, and P. Walsh (2011), New tools in comparative political economy: the Database of Political Institutions. World Bank Economic Review 15 (1): 165-176.

Dalton, R. (2011). Left-Right Orientations, Context, and Voting Choice." In R.Dalton and C. Anderson (eds.), Citizens, Context and Choice: How Context Shapes Citizens' Electoral Choices. Oxford: Oxford University Press, 2011. 


\section{Age and probability of being contacted by parties}

Figure A1. Age and probability of being contacted by parties in different ways in selected countries: new contacts do not compensate for age differential (blue: new contacts; red: traditional contacts; black: any contact).

Australia

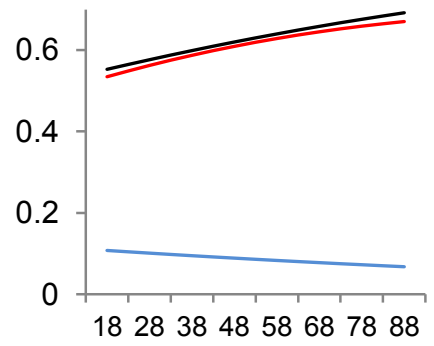

Switzerland

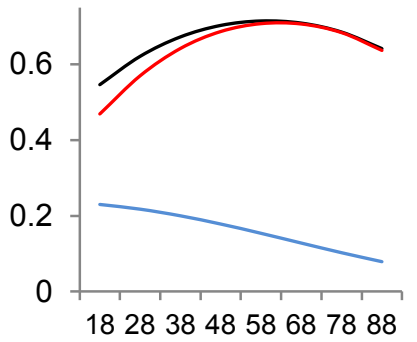

Taiwan

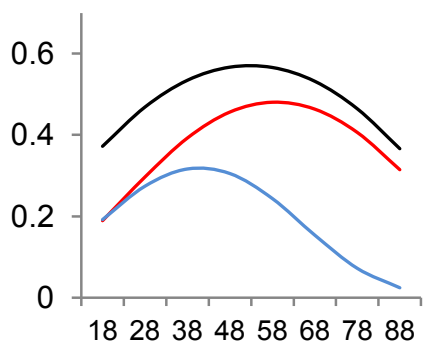

N Zealand 14

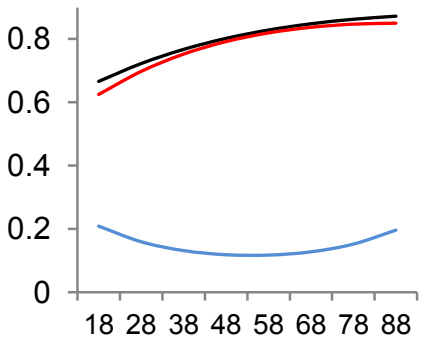

Iceland

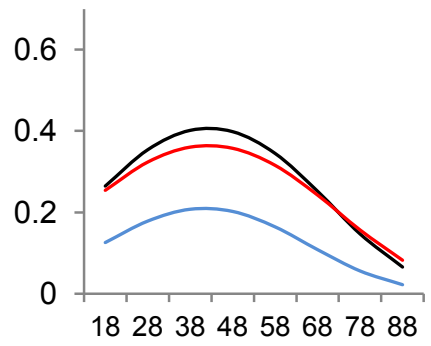

Serbia

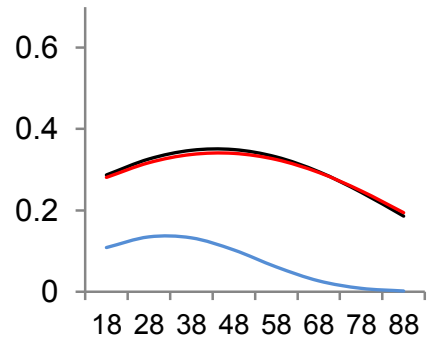

Greece

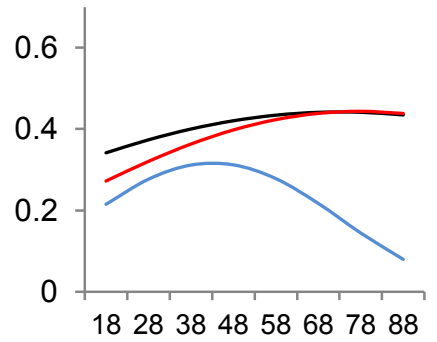

Israel

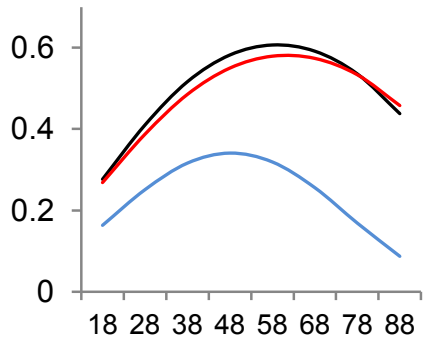

S. Korea

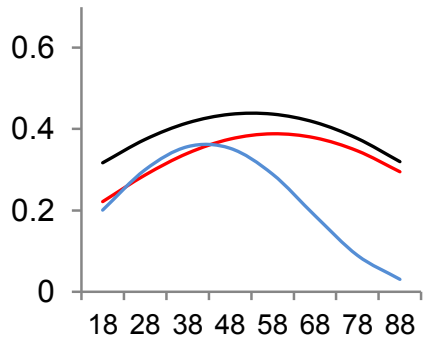


USA

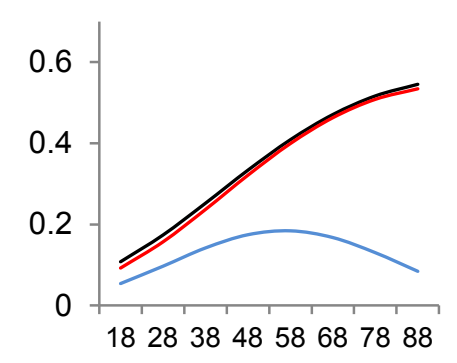

Slovakia

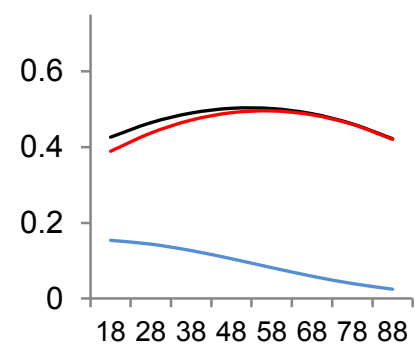

S Africa

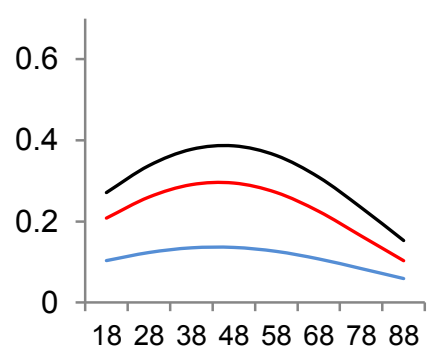


Figure A2. Age and probability of being contacted by parties in different ways in selected countries: relationship between age and all kinds of contacts tends to be negative (blue: new contacts; red: traditional contacts; black: any contact).

Sweden

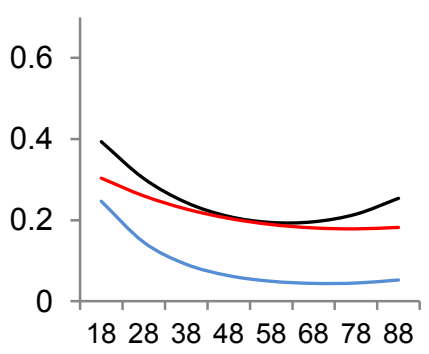

Norway

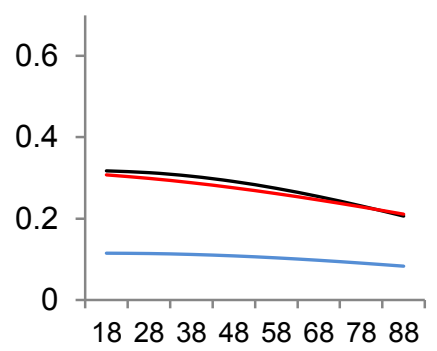

Figure A3. Age and probability of being contacted by parties in different ways in selected countries: no relationship between contact and age (blue: new contacts; red: traditional contacts; black: any contact).

Austria

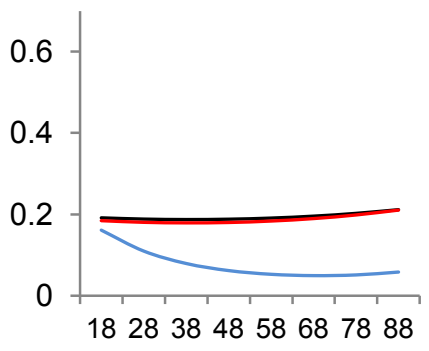

Turkey

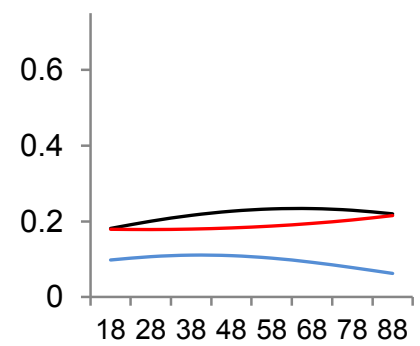

Czech

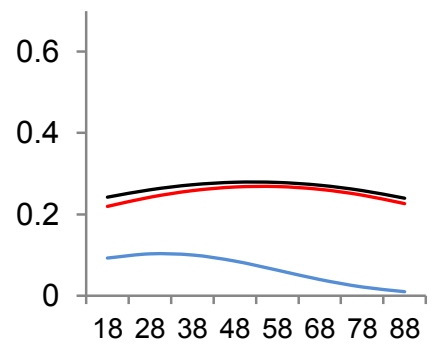

Mexico 15

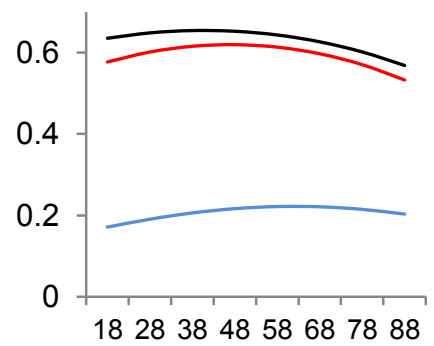


Figure A4. Age and probability of being contacted by parties in different ways in selected countries: new contacts compensate for age differential in traditional contacts (blue: new contacts; red: traditional contacts; black: any contact).

Mexico 12

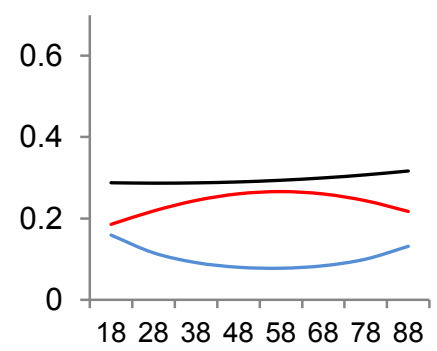

Finland

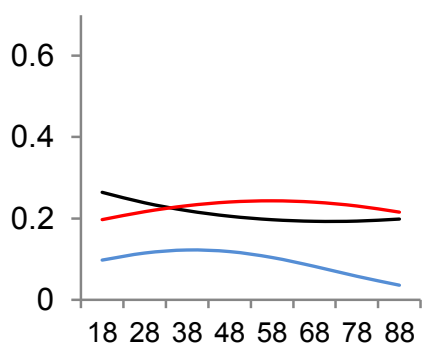

